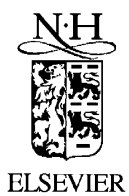

Available online at www.sciencedirect.com

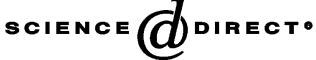

Journal of Financial Economics 70 (2003) 261-291

www.elsevier.com/locate/econbase

\title{
The maturity of debt issues and predictable variation in bond returns ${ }^{2 / 3}$
}

\author{
Malcolm Baker ${ }^{\mathrm{a}, *}$, Robin Greenwood ${ }^{\mathrm{a}}$, Jeffrey Wurgler ${ }^{\mathrm{b}}$ \\ ${ }^{a}$ Harvard Business School, Harvard University, Morgan Hall, Boston, MA 02163, USA \\ ${ }^{\mathrm{b}}$ NYU Stern School of Business, 44 West Fourth Street, New York, NY 10012, USA
}

Received 15 August 2001; accepted 17 May 2002

\begin{abstract}
The maturity of new debt issues predicts excess bond returns. When the share of long-term debt issues in total debt issues is high, future excess bond returns are low. This predictive power comes in two parts. First, inflation, the real short-term rate, and the term spread predict excess bond returns. Second, these same variables explain the long-term share, and together account for much of its own ability to predict excess bond returns. The results are consistent with survey evidence that firms use debt market conditions in an effort to determine the lowest-cost maturity at which to borrow.
\end{abstract}

(C) 2003 Elsevier B.V. All rights reserved.

JEL classification: G32; G12; G14

Keywords: Maturity structure; Term structure; Interest rates; Market efficiency

\footnotetext{
${ }^{25}$ We thank Nick Barberis, John Campbell, Gene D'Avolio, Ned Elton, Jonathan Ingersoll, Andrew Jeffrey, Scott Mayfield, Lasse Pedersen, Andre Perold, Mike Rashes, David Scharfstein, Andrei Shleifer, Erik Stafford, Jeremy Stein, Sheridan Titman, Peter Tufano, Luis Viceira, Jessica Wachter, Robert Whitelaw, and seminar participants at Duke University, London Business School, Purdue University, the University of Pennsylvania, and the Financial Decisions and Control conference at Harvard Business School for helpful comments. We thank Ibbotson Associates and Glen Taksler for data. Baker and Wurgler gratefully acknowledge financial support from the Division of Research of the Harvard Graduate School of Business Administration. Greenwood gratefully acknowledges financial support from the National Science Foundation.

*Corresponding author.

E-mail address: mbaker@hbs.edu (M. Baker).
} 


\section{Introduction}

How corporations should manage financial policy to minimize the cost of capital is a question of great theoretical and practical interest. In efficient, integrated, and otherwise perfect capital markets, Modigliani and Miller (1958) and Stiglitz (1974) show that financial policy cannot reduce the cost of capital. Their key insight is that in such idealized markets, the costs of different forms of capital do not vary independently, so there is never any gain to substituting between debt and equity, for example, or between short- and long-term debt.

Nonetheless, there is considerable evidence that equity financing is tied to stock return predictability. Firms tend to issue equity when the equity premium is low, and when their idiosyncratic returns are low. They tend to repurchase equity when idiosyncratic returns are high. ${ }^{1}$ These patterns are interesting because they are not straightforward implications of the Modigliani-Miller view or its standard extensions. One prominent explanation for these patterns is that firms are timing an inefficient or segmented capital market, and another is that optimal capital structure and rational expected returns vary together over time. It is difficult to distinguish between these explanations, and the truth may involve both.

In this paper, we ask whether time series variation in the maturity of debt issues is tied to predictability in excess long-term bond returns. Relative to the literature on equity financing patterns, and relative to the actual importance of debt financing in the U.S. economy, the literature on debt financing patterns is surprisingly undeveloped. We find strong evidence that firms tend to borrow long-term when subsequent long-term bond returns are predictably low. Then we examine whether this pattern is more consistent with debt market timing or with an explanation that involves time-varying optimal debt maturity and rational variation in expected bond returns.

The notion that debt maturity is related to debt market conditions can be found in several prior studies. Bosworth (1971), White (1974), Taggart (1977), and Marsh (1982) find that the level of debt issues is sensitive to various measures of interest rates. In firm-level data, Guedes and Opler (1996) document that the maturity of issues is negatively related to the term spread (the difference between the yields of long- and short-term government debt), and Barclay and Smith (1995) and Stohs and Mauer (1996) find a similar result - that the maturity of debt on balance sheets is negatively related to the term spread. While suggestive, none of these results address whether debt maturity is related to the cost of borrowing at different maturities, because none of them examine returns data.

Our approach is to see whether variation in the maturity of new debt issues is connected to the debt market conditions that forecast excess bond returns, and to

\footnotetext{
${ }^{1}$ Baker and Wurgler (2000) document that firms issue more equity, as a share of total equity and debt issues, when the equity premium is low. Stigler (1964), Ritter (1991), Loughran and Ritter (1995), Speiss and Affleck-Graves (1995), and Brav and Gompers (1997) find that (idiosyncratic) equity returns are low following equity issues. Ikenberry et al. (1995) find that (idiosyncratic) equity returns are high following repurchases. See Baker and Wurgler (2002) and Ritter (2003) for more comprehensive surveys of the market timing literature.
} 
future excess bond returns themselves. We use two sources of debt issues data: the Federal Reserve Flow of Funds (Board of Governors of the Federal Reserve System, various issues) and firm-by-firm aggregations of Compustat. The debt market variables that we use to capture predictable variation in excess bond returns are inflation (actual or expected), the real short-term interest rate (realized or ex ante), the term spread, the credit spread, and the credit term spread. Future excess bond returns are measured as the excess return of Treasury bonds over Treasury bills, and as the excess return of high-grade corporate bonds over commercial paper. Most of our tests use annual data covering 1953 through 2000.

Our main results are the following. First, inflation, the real short-term interest rate, and the term spread predict excess bond returns; when these market conditions variables are high, future excess bond returns are high over the next one to three years. Second, the long-term share in aggregate total debt issues is negatively related to each of these variables. When put together, these two results indicate that firms tend to borrow long when excess bond returns are predictably low, supporting our main hypothesis. We also verify the predictability hypothesis directly by showing that the long-term share in total debt issues is a good univariate predictor of excess bond returns, taking on high values when future excess bond returns are low. The three-year cumulative excess government bond returns that follow a bottom-quartile share average 21.8 percentage points, while the returns following a top-quartile share average -5.2 percentage points. In a more disaggregated analysis using Compustat data, we find that these patterns tend to be strongest among large firms, old firms, dividend-paying firms, and investment-grade firms.

These results establish that debt maturity choice is closely connected to predictable variation in excess bond returns. We favor the interpretation that managers are trying to time the debt market, but despite suggestive evidence one cannot determine whether they are reducing the overall cost of capital because of the usual difficulties of testing market efficiency. Several factors point to this interpretation. Using the approach of Schwert (1989), we cannot connect the long-term share to risk that seems likely to require a rational risk premium. Also, a review of the theory of optimal maturity structure uncovers no straightforward reason why optimal debt maturity would be inversely related to rational variation in expected excess bond returns. Finally, and most convincing, the survey by Graham and Harvey (2001) points directly to debt market timing as a motivation in debt financing decisions. A large fraction of chief financial officers prefer short-term debt "when short-term interest rates are low compared to long-term rates" and when they are "waiting for long-term interest rates to decline.", Indeed, these statements are more common among some of the same types of firms that our Compustat tests identify as particularly sensitive to debt market conditions.

Our results are complemented by an interesting recent study by Kaplin and Levy (2001). They use a variable like our long-term share to predict excess bond returns at

\footnotetext{
${ }^{2}$ Managers focus more on public information about general debt market conditions than private information about credit quality. Graham and Harvey find that only $9 \%$ of managers state that "we expect our credit rating to improve, so we borrow short-term until it does."
} 
higher frequencies, one to six months. The relative advantage of our data is that they allow us to study a longer period, almost five decades versus the one decade in the Kaplin and Levy study. This permits us to more thoroughly document the time series relationships between debt issue maturity and market conditions, which display the bulk of their variation at horizons longer than a few months. Also, for managers trying to gain a cost advantage through timing, the cumulative return over the life of the security is more relevant than a short-horizon return. Our longer prediction horizons are therefore more useful for evaluating the debt market timing hypothesis.

The paper proceeds as follows. Section 2 summarizes the predictable variation in excess bond returns related to debt market conditions. Section 3 uses debt issues data from the Federal Reserve Flow of Funds to examine how market conditions affect the debt issue maturity and its predictive power for excess bond returns. Section 4 examines these questions using aggregated Compustat data. Section 5 discusses alternative interpretations for the results. Section 6 concludes.

\section{Debt market conditions and predictable variation in excess bond returns}

In this section we describe the predictable variation in excess bond returns. This is a prerequisite to understanding the relation between the maturity of debt issues and expected excess bond returns, the topic of subsequent sections.

\subsection{Debt market conditions and excess bond returns data}

The basic data include annual time series from 1953 through 2000 on the maturity of corporate debt issues, debt market conditions such as interest rates and inflation, and excess bond returns. The Federal Reserve pegged nominal Treasury bill rates up to 1952 , so most academic studies of the government bond market begin in 1953 . We follow this convention.

Debt market conditions are represented by seven variables: inflation; expected inflation; the realized real short-term rate; the ex ante real short-term rate; the term spread; the credit spread; and the credit term spread. Actual inflation $\left(\pi_{A t}\right)$ is the annual percentage change in the Consumer Price Index. Expected inflation $\left(\pi_{E t}\right)$ is the expected appreciation of the Consumer Price Index over the coming year estimated following the procedure in Fama and Gibbons (1982). ${ }^{3}$ The realized real short-term rate $\left(y_{G S t}-\pi_{A t}\right)$ is estimated as the annualized December Treasury bill return minus actual inflation. The ex ante real short-term rate $\left(y_{G S t}-\pi_{E t}\right)$ is

\footnotetext{
${ }^{3}$ We implement the Kalman filter procedure of Fama and Gibbons (1982, Table 1, Eqs. (6) and (8)), decomposing the Treasury bill yield into expected inflation and the real short-term interest rate. There are two concerns with this analysis. First, the decomposition depends on a structural assumption about the process of the real interest rate. Second, we are using an in-sample estimation of the real interest rate to forecast future returns. Fortunately, none of our qualitative conclusions are sensitive to whether we use actual inflation or this measure of expected inflation, and we report results both ways.
} 
estimated as the annualized December Treasury bill return minus expected inflation. The term spread $\left(y_{G L t}-y_{G S t}\right)$ is the difference between the December Treasury bond yield and the annualized December Treasury bill return. Most research on bond return predictability focuses on the term spread (Shiller, 1979; Shiller et al., 1983; Fama 1984; Keim and Stambaugh, 1986; Fama and Bliss, 1987; Fama and French, 1989; Campbell and Shiller, 1991), while Ferson and Harvey (1991, 1993) consider a larger set of components of the term structure. The credit spread $\left(y_{C S t}-y_{G S t}\right)$ is the difference between the December commercial paper yield and the annualized December Treasury bill return. Finally, the credit term spread $\left(\left(y_{C L t}-y_{G L t}\right)-\right.$ $\left.\left(y_{C S t}-y_{G S t}\right)\right)$ involves the December Moody's Baa corporate bond yield and the other yields just introduced. These series are based on data from Ibbotson Associates.

Excess bond returns are measured by an index of Treasury bonds over bills and an index of investment-grade corporate bonds over commercial paper. Returns on long-term government bonds $\left(r_{G L t}\right)$, short-term government bills $\left(r_{G S t}\right)$, highgrade long-term corporate bonds $\left(r_{C L t}\right)$, and commercial paper $\left(r_{C S t}\right)$ are from Ibbotson Associates. The government and corporate bond indexes track portfolios that are continually redefined so as to keep a constant 20 -year maturity. ${ }^{4}$ Excess government and corporate bond returns in year $t$ are $\left(r_{G L t}-r_{G S t}\right)$ and $\left(r_{C L t}-r_{C S t}\right)$, respectively. Cumulative excess returns are denoted $\left(R_{G L t+k}-R_{G S t+k}\right)$ and $\left(R_{C L t+k}-\right.$ $\left.R_{C S t+k}\right)$, where the accumulation includes years $t+1$ through $t+k$. In our tests we cumulate returns for up to three years. In principle, these excess returns correspond to the actual relative cost of straight short- and long-term debt for a representative firm. The most relevant period is the life of the bond, which could be ten or more years, though with open market repurchases, the relevant period could be any shorter length. In any case, beyond three years, we do not have enough nonoverlapping samples to do meaningful statistical analysis.

These variables are summarized in Table 1 and Fig. 1. Panel A of Fig. 1 reveals a loose negative correlation between inflation (actual or expected) and the real shortterm rate (realized or ex ante) since 1953, indicating that the nominal short rate is an important source of variation. Panel B displays the inversion of the yield curve at several points in the 1970s. Term spread inversions appear to portend recessions (Fama and French, 1989) and the credit spread appears to be somewhat countercyclical. Panel $\mathrm{C}$ shows the high volatility of both excess government and corporate bond returns in the last 30 years. It also shows the high correlation (0.95) between excess Treasury bond returns and excess high-grade corporate bond returns.

\footnotetext{
${ }^{4}$ The government bond returns series uses data from the Wall Street Journal for 1977 through 2000 and the Center for Research in Security Prices Government Bond File for 1976 and earlier. The corporate bond returns series uses the Salomon Brothers Long-Term High-Grade Corporate Bond Index, which includes most Aaa- and Aa-rated bonds, for 1969 through 2000, a backdated Salomon Brothers return series for 1968 and earlier.
} 
Table 1

Debt market conditions, excess bond returns, and the maturity of corporate debt issues, 1953-2000

Mean, standard deviation, autocorrelation coefficient, and extreme values of basic annual variables. All variables are expressed in percentage terms. In Panel A, we decompose the annualized December Treasury bill return into actual inflation $\left(\pi_{A}\right)$ and the realized real short-term rate $\left(y_{G S}-\pi_{A}\right)$. We also construct expected inflation $\left(\pi_{E}\right)$ and the ex ante real interest rate $\left(y_{G S}-\pi_{E}\right)$ following Fama and Gibbons (1982). The term spread $\left(y_{G L}-y_{G S}\right)$ is the difference between the annualized December long-term government bond yield and the annualized December Treasury bill return. The credit spread $\left(y_{C S}-y_{G S}\right)$ is the difference between the commercial paper yield and the annualized December Treasury bill return. The credit term spread $\left(\left(y_{C L}-y_{G L}\right)-\left(y_{C S}-y_{G S}\right)\right)$ is the difference between the December Baa corporate bond yield and the December long-term government bond yield minus the credit spread. In Panel B, excess bond returns are measured as the difference between the annual return on long-term government bonds and Treasury bills $\left(r_{G L}-r_{G S}\right)$ and the difference between the annual return on corporate bonds and commercial paper $\left(r_{C L}-r_{C S}\right)$. All bond market data are from Ibbotson Associates. In Panel C, the data are from the Federal Reserve Flow of Funds. Long-term debt includes industrial revenue bonds, corporate bonds, and mortgages. Total debt also includes commercial paper, bank loans not elsewhere classified, and other short-term loans and advances. All short-term debt is assumed to be new short-term issues. The change in long-term debt plus one-tenth of lagged long-term debt is assumed to be new long-term issues.

\begin{tabular}{lrrrrrr}
\hline$(\%)$ & $N$ & Mean & SD & $\rho$ & Min & Max \\
\hline Panel A: Debt market conditions & & & & & & \\
$\pi_{A t}$ & 47 & 4.03 & 3.74 & 0.70 & -0.76 & 18.20 \\
$\pi_{E t}$ & 47 & 4.04 & 3.16 & 0.79 & -0.50 & 13.31 \\
$y_{G S t}-\pi_{A t}$ & 47 & 1.65 & 2.18 & 0.76 & -2.92 & 6.60 \\
$y_{G S t}-\pi_{E t}$ & 47 & 1.63 & 1.82 & 0.52 & -3.50 & 5.28 \\
$y_{G L t}-y_{G S t}$ & 47 & 1.12 & 1.61 & 0.40 & -4.87 & 4.41 \\
$y_{C S t}-y_{G S t}$ & 47 & 0.61 & 0.57 & 0.34 & -0.40 & 2.81 \\
$\left(y_{C L t}-y_{G L t}\right)-\left(y_{C S t}-y_{G S t}\right)$ & 47 & -0.01 & 0.66 & 0.38 & -1.91 & 1.19 \\
Panel B: Excess bond returns & & & & & & \\
$r_{G L t+1}-r_{G S t+1}$ & 47 & 1.32 & 10.28 & -0.12 & -13.65 & 26.97 \\
$r_{C L t+1}-r_{C S t+1}$ & 47 & 0.66 & 9.66 & -0.01 & -14.86 & 26.95 \\
Panel C: Maturity of corporate debt & & & & & & \\
$d_{L t} / D_{t-1}$ & 47 & 11.42 & 2.06 & 0.45 & 7.42 & 17.09 \\
$d_{S t} / D_{t-1}$ & 47 & 41.44 & 6.01 & 0.90 & 29.74 & 54.70 \\
$d_{L t} /\left[d_{L t}+d_{S t}\right]$ & 47 & 21.78 & 3.98 & 0.67 & 14.10 & 28.96 \\
\hline
\end{tabular}

\subsection{Predicting excess bond returns with debt market conditions}

Table 2 shows regressions that predict excess bond returns using inflation, the real short-term rate, the term spread, the credit spread, and the credit term spread. Some of the closest antecedents for these specifications are Ferson and Harvey (1991, 1993), who study monthly returns. The first specification in Panel A predicts oneyear-ahead excess Treasury bond returns,

$$
\begin{aligned}
r_{G L t+1}-r_{G S t+1}= & a+b \pi_{t}+c\left(y_{G S t}-\pi_{t}\right)+d\left(y_{G L t}-y_{G S t}\right)+e\left(y_{C S t}-y_{G S t}\right) \\
& +f\left(\left(y_{C L t}-y_{G L t}\right)-\left(y_{C S t}-y_{G S t}\right)\right)+u_{t+1},
\end{aligned}
$$


Panel A. Inflation (actual - thick line, expected - thin) and real short-term rate (actual - short dash, expected - long)

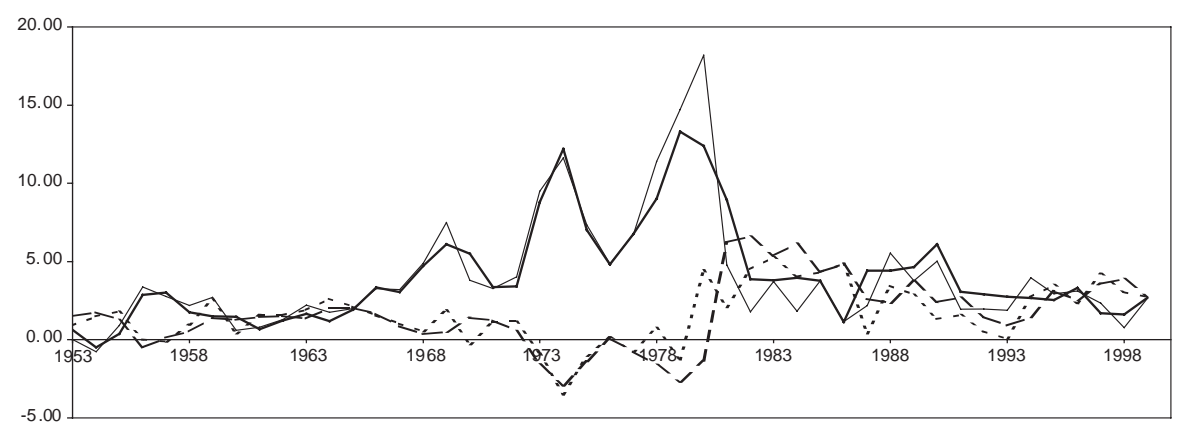

Panel B. Term spread (solid), credit spread (short dash), and the credit term spread (long dash)

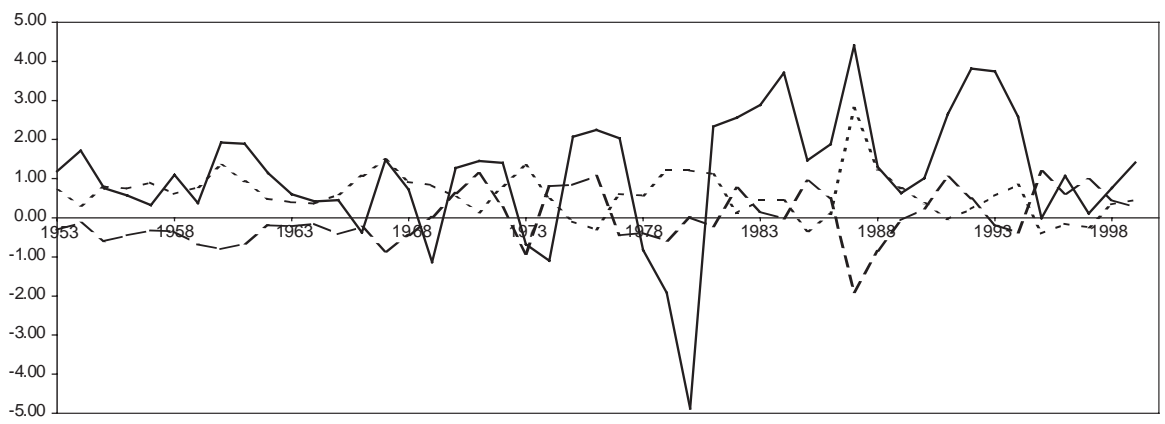

Panel C. Excess government (solid) and corporate (dash) bond returns

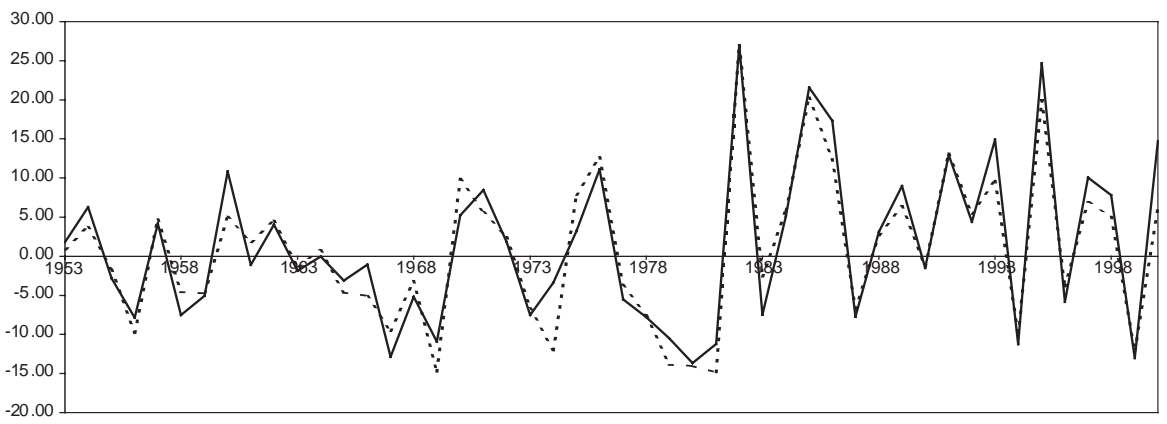

Fig. 1. Debt market conditions and excess bond returns, 1953-2000. In Panel A, we decompose the annualized December Treasury bill return into actual inflation $\left(\pi_{A}\right)$ and the realized real short-term rate $\left(y_{G S}-\pi_{A}\right)$. We also construct expected inflation $\left(\pi_{E}\right)$ and the ex ante real interest rate $\left(y_{G S}-\pi_{E}\right)$ following Fama and Gibbons (1982). In Panel B, the term spread $\left(y_{G L}-y_{G S}\right)$ is the difference between the annualized December long-term government bond yield and the annualized December Treasury bill return. The credit spread $\left(y_{C S}-y_{G S}\right)$ is the difference between the commercial paper yield and the annualized December Treasury bill return. The credit term spread $\left(\left(y_{C L}-y_{G L}\right)-\right.$ $\left.\left(y_{C S}-y_{G S}\right)\right)$ is the difference between the December Baa corporate bond yield and the December long-term government bond yield minus the credit spread. In Panel C, excess bond returns are measured as the difference between the annual return on long-term government bonds and Treasury bills $\left(r_{G L}-r_{G S}\right)$ and the difference between the annual return on corporate bonds and commercial paper $\left(r_{C L}-r_{C S}\right)$. All data are from Ibbotson Associates. 
Table 2

Debt market conditions and excess bond returns

OLS regressions predicting excess bond returns using inflation $(\pi)$, the real short-term rate $\left(y_{G S}-\pi\right)$, the term spread $\left(y_{G L}-y_{G S}\right)$, the credit spread $\left(y_{C S}-y_{G S}\right)$, and the credit term spread $\left(\left(y_{C L}-y_{G L}\right)-\left(y_{C S}-y_{G S}\right)\right)$. We also reduce the regressions to a standardized univariate prediction. The specification for predicting one-year-ahead excess government bond returns, for example, is

$$
r_{G L t+1}-r_{G S t+1}=a+b \pi_{t}+c\left(y_{G S t}-\pi_{t}\right)+d\left(y_{G L t}-y_{G S t}\right)+e\left(y_{C S t}-y_{G S t}\right)+f\left(\left(y_{C L t}-y_{G L t}\right)-\left(y_{C S t}-y_{G S t}\right)\right)+g\left(\hat{R}_{L t+1}-\hat{R}_{S t+1}\right)+u_{t+1} .
$$

Excess bond returns are expressed in percentage terms. The independent variables are standardized to have unit variance. In Panel A, the dependent variable is the excess return on long-term government bonds over Treasury bills $\left(r_{G L}-r_{G S}\right)$ and inflation is expected inflation $\left(\pi_{E}\right)$. In Panel B, inflation is actual inflation $\left(\pi_{A}\right)$. In Panel C, the dependent variable is the excess return of corporate bonds over commercial paper $\left(r_{C L}-r_{C S}\right)$ and inflation is expected inflation $\left(\pi_{E}\right)$. Each panel predicts one-year-ahead, two-year-ahead, and three-year-ahead returns $(r)$ as well as cumulative three-year returns $(R) . t$-statistics are heteroskedasticity robust and correct for time-series dependence up to three lags.

\begin{tabular}{|c|c|c|c|c|c|c|c|c|c|c|c|c|c|c|}
\hline \multirow[b]{2}{*}{$(\%)$} & \multirow[b]{2}{*}{$N$} & \multicolumn{2}{|c|}{$\pi_{t}$} & \multicolumn{2}{|c|}{$y_{G S t}-\pi_{t}$} & \multicolumn{2}{|c|}{$y_{G L t}-y_{G S t}$} & \multicolumn{2}{|c|}{$y_{C S t}-y_{G S t}$} & \multicolumn{2}{|c|}{$\left(y_{C L t}-y_{G L t}\right)-\left(y_{C S t}-y_{G S t}\right)$} & \multicolumn{2}{|c|}{$\hat{R}_{L t+k}-\hat{R}_{S t+k}$} & \multirow[b]{2}{*}{$R^{2}$} \\
\hline & & $b$ & {$[t]$} & $c$ & {$[t]$} & $d$ & {$[t]$} & $e$ & {$[t]$} & $f$ & {$[t]$} & $g$ & {$[t]$} & \\
\hline \multicolumn{15}{|c|}{ Panel A: Excess government bond returns $\left(\pi_{t}=\pi_{E t}\right)$} \\
\hline$r_{G L t+2}-r_{G S t+2}$ & 46 & 1.66 & {$[0.67]$} & 3.60 & [2.39] & -0.53 & {$[-0.25]$} & 5.67 & [1.32] & 4.17 & {$[1.14]$} & & & 0.14 \\
\hline$r_{G L t+3}-r_{G S t+3}$ & 45 & 3.11 & [1.38] & 3.99 & {$[2.77]$} & 0.54 & {$[0.22]$} & 0.77 & {$[0.20]$} & -0.50 & {$[-0.17]$} & & & 0.11 \\
\hline$R_{G L t+3}-R_{G S t+3}$ & 45 & 8.70 & {$[1.65]$} & 11.26 & [5.54] & 4.44 & [1.12] & 3.42 & {$[0.40]$} & 1.80 & {$[0.27]$} & & & 0.41 \\
\hline$r_{G L t+1}-r_{G S t+1}$ & 47 & & & & & & & & & & & 5.14 & {$[5.52]$} & 0.25 \\
\hline \multicolumn{15}{|c|}{ Panel B: Excess government bond returns $\left(\pi_{t}=\pi_{A t}\right)$} \\
\hline$r_{G L t+1}-r_{G S t+1}$ & 47 & 4.65 & [1.68] & 5.63 & {$[2.22]$} & 4.83 & [4.85] & -1.73 & {$[-0.40]$} & -0.45 & {$[-0.13]$} & & & 0.24 \\
\hline$r_{G L t+2}-r_{G S t+2}$ & 46 & 1.41 & {$[0.43]$} & 7.80 & {$[2.30]$} & 0.47 & {$[0.27]$} & 7.16 & {$[1.46]$} & 5.34 & {$[1.30]$} & & & 0.16 \\
\hline$r_{G L t+3}-r_{G S t+3}$ & 45 & 3.62 & {$[1.28]$} & 7.52 & [2.37] & 1.48 & [0.82] & 1.52 & {$[0.33]$} & 0.18 & {$[0.05]$} & & & 0.10 \\
\hline$R_{G L t+3}-R_{G S t+3}$ & 45 & 10.11 & {$[1.55]$} & 21.19 & [5.23] & 7.11 & [2.97] & 5.57 & {$[0.56]$} & 3.73 & {$[0.49]$} & & & 0.40 \\
\hline$r_{G L t+1}-r_{G S t+1}$ & 47 & & & & & & & & & & & 5.06 & {$[5.53]$} & 0.24 \\
\hline$R_{G L t+3}-R_{G S t+3}$ & 45 & & & & & & & & & & & 10.58 & [5.85] & 0.40 \\
\hline$r_{C L t+1}-r_{C S t+1}$ & 47 & 2.63 & {$[1.40]$} & 2.92 & {$[2.44]$} & 4.11 & [3.52] & 0.78 & {$[0.25]$} & 1.92 & {$[0.70]$} & & & 0.30 \\
\hline$r_{C L t+2}-r_{C S t+2}$ & 46 & 2.04 & {$[0.74]$} & 3.78 & [2.84] & -0.78 & {$[-0.39]$} & 5.04 & [1.08] & 3.34 & {$[0.81]$} & & & 0.16 \\
\hline$r_{C L t+3}-r_{C S t+3}$ & 45 & 3.37 & {$[1.47]$} & 3.90 & [3.05] & 0.38 & {$[0.16]$} & 1.32 & {$[0.30]$} & -1.15 & {$[-0.36]$} & & & 0.14 \\
\hline$R_{C L t+3}-R_{C S t+3}$ & 45 & 7.91 & {$[1.45]$} & 11.11 & {$[5.52]$} & 3.65 & {$[1.00]$} & 6.30 & [0.69] & 3.50 & {$[0.47]$} & & & 0.41 \\
\hline$r_{C L t+1}-r_{C S t+1}$ & 47 & & & & & & & & & & & 5.23 & {$[5.01]$} & 0.30 \\
\hline$R_{C L t+3}-R_{C S t+3}$ & 45 & & & & & & & & & & & 10.67 & [6.24] & 0.41 \\
\hline
\end{tabular}


using expected inflation $\left(\pi_{E t}\right)$ to measure inflation. Other specifications in Panel A predict two- and three-year-ahead returns and cumulative three-year-ahead returns. Panel B replaces expected inflation with actual inflation, and Panel $\mathrm{C}$ examines corporate bond returns. The standard errors in all regressions are adjusted for heteroskedasticity and autocorrelation of up to three lags using the procedure of Newey and West (1987). The alternative adjustments of Hansen and Hodrick (1980) and Hodrick (1992) to correct for overlapping cumulative returns do not change the basic inferences. Returns are expressed in percentage terms while the independent variables are standardized to have unit variance. (Throughout the paper we use the convention of standardizing the independent variables. This allows the relative magnitude of the coefficients to be easily assessed, since each one measures the effect of a one-standard-deviation change in the independent variable.)

Table 2 shows that future excess government bond returns are positively related to inflation (actual or expected), the real short rate (realized or ex ante), and the term spread. As is widely recognized, the term spread is a useful one-year-ahead predictor, but the predictive power of inflation and particularly the real short rate is also notable. For cumulative three-year returns, the real short rate emerges as the strongest predictor, although precise statistical inference is difficult in overlapping return regressions.

Of particular concern is the $R^{2}$ statistic. Mean reversion, overlapping data, and the persistence of the independent variables lead to an $R^{2}$ statistic that could automatically rise with horizon (e.g. Campbell et al., 1997, p. 272). In addition, Kirby (1997) derives a small-sample bias in $R^{2}$ that increases with the overlap. Intuitively, the bias comes from two facts: First, the standard error of the $R^{2}$ statistic increases with horizon; and second, the $R^{2}$ is never below zero. As a result, the $R^{2}$ statistic must not be viewed as an unbiased estimate of model fit.

In the last two rows of each panel we combine the five market conditions, each weighted by its least squares coefficient, into a single fitted value. By construction, this fitted value explains the same fraction of variation in future returns. Later in the paper, we will use this fitted value as a summary measure of expected excess bond returns, and we will also outline the alternative interpretations of the predictability that it captures. ${ }^{5}$ The purpose of Table 2 is simply to demonstrate that a set of

\footnotetext{
${ }^{5}$ Combining this information into a single regressor also allows us to address the small-sample bias analyzed in Nelson and Kim (1993) and Stambaugh (1999) in a simple manner. Those authors point out that autocorrelated predictors whose innovations are negatively (positively) correlated with innovations in excess returns will have upward-biased (downward-biased) estimates. This suggests a potential statistical problem with the Table 2 results. First, inflation, the real short rate, and the term spread add up to the long rate. Second, the long rate is highly autocorrelated. Third, its innovations are almost perfectly negatively correlated with innovations in excess bond returns. However, it turns out that the fitted value has a correlation of only 0.6 with the long rate, because the coefficients on inflation, the real short rate, and the term spread - when not standardized - are quite different. More importantly, the innovations in the fitted value are statistically uncorrelated with innovations in the long rate. The bias-adjusted estimate for the fitted value coefficient suggested by Stambaugh (1999) confirms that the combined predictive power of these market conditions is robust. Because the innovations in the fitted value are also uncorrelated with innovations in excess returns, the adjustment has no effect on the coefficient. In Panel A, for example, the bias-adjusted coefficient for the one-year-ahead fitted value is 5.17 (unreported), larger than the leastsquares estimate reported in the table.
} 
market conditions variables can predict a nontrivial amount of excess bond return variation. This in turn suggests the hypothesis that the relative cost of long-term borrowing is predictable enough to influence the maturity of corporate debt issues whether predictable variation represents inefficiency or compensation for risk is a topic we defer until our discussion section. We turn now to this hypothesis.

\section{Debt issue maturity and the relative cost of long-term debt: Flow of Funds sample}

Here we explore how the maturity of corporate debt issues is related to market conditions and predictable variation in excess bond returns. We focus on aggregate time series data because we are most interested in time series relations with government bond yields and returns, for which there is a single observation in each time period. (Firm-level data do not help us to study such relationships.) In this section we analyze aggregate debt issues data from the Federal Reserve Flow of Funds, following Bosworth (1971), White (1974), and Taggart (1977), for example. Of course, this fully aggregated data hides any cross-sectional differences in behavior that might be due to variation in firm characteristics. We explore this possibility in a subsequent section, by analyzing time series of debt issues generated from various firm-by-firm Compustat aggregations.

\subsection{Flow of Funds debt issues data}

The Federal Reserve gathers capital market flows data from a variety of internal and commercial sources. The available accounts cover 1945 through 2000. As mentioned above, we follow recent fixed income research and start at 1953. (Most results have slightly greater statistical significance if we extend the data back to 1945.) The data are taken from the credit market liabilities of the nonfarm, nonfinancial corporate business sector (Table L.102 in the accounts). We ignore noncredit market liabilities because we lack information on their maturity and because they are less likely to be affected by debt market conditions.

Our intuition is that, each year, corporations make explicit decisions regarding maturity. Assuming that existing long-term debt cannot be easily retired, the relevant decision concerns the total of all existing short-term debt, the maturing portion of long-term debt, and the increase in total debt outstanding. The Federal Reserve defines short-term credit market debt outstanding as the sum of "commercial paper," "bank loans not elsewhere classified," and "other loans and advances." As reported by the Guide to the Flow of Funds Accounts, commercial paper typically has a maturity of six months or less. Bank loans not elsewhere classified refers to commercial and industrial loans held by U.S. banks. Other loans and advances includes loans to nonfarm nonfinancial corporate business held by savings institutions and the government, acceptance liabilities to banks, foreign loans to U.S. entities, and business loans held by issuers of asset-backed securities. Over the sample, commercial paper represents an average of $6.2 \%$ of short-term debt. Bank debt and other loans and advances average $67.1 \%$ and $26.7 \%$ of total short-term 
debt, respectively. These proportions are fairly stable throughout the sample. We define short-term debt issues $\left(d_{S t}\right)$ as the ending level of short-term credit market debt outstanding.

Long-term credit market debt outstanding is defined by the Federal Reserve as the sum of "industrial revenue bonds," "corporate bonds," and "mortgages." Industrial revenue bonds are issued by state and local governments to finance private investment and are secured in principal by the industrial user of the bonds. Mortgages include construction loans, multifamily mortgage debt, and commercial mortgage debt, less commercial mortgage debt of nonprofit organizations, and less commercial mortgage debt of nonfarm noncorporate business. Over the sample, industrial revenue bonds average only $3.8 \%$ of total long-term debt. Corporate bonds and mortgages respectively average $73.8 \%$ and $22.3 \%$ of total long-term debt. These figures are also relatively stable through the sample. We define long-term debt issues $\left(d_{L t}\right)$ as the gross change in the level of long-term credit market debt outstanding, plus one-tenth the level of long-term debt in the previous year. This assumes that one-tenth of long-term debt matures each year. ${ }^{6}$

To measure the level of debt issues while controlling for growth in the economy, we scale issues by lagged total credit-market debt outstanding $\left(d_{S t} / D_{t-1}\right.$ and $\left.d_{L t} / D_{t-1}\right)$. To control for the level of total issues and thereby isolate the maturity decision, we construct the long-term share in total debt issues $\left(d_{L t} /\left[d_{L t}+d_{S t}\right]\right)$. This variable is our main focus in the rest of the paper.

We examine the level of the long-term share in debt issues for two reasons. First, this roughly corresponds to an aggregate version of Guedes and Opler (1996), who study maturity choice in a large cross-section, and to a maturity structure version of Baker and Wurgler (2000), who study the marketwide decision to issue equity versus debt of any maturity. Second, our aim is to study the effect of market conditions on maturity choice. If the long-term share is a noisy measure of underlying market conditions and these market conditions are persistent, levels of the long-term share will more accurately measure the preference for long-term debt than changes, which will be dominated by measurement error.

The strengths of the Flow of Funds data are its consistent definitions, its availability over a long time span (crucial for our purposes), and its comprehensive coverage. At the same time, the data have several shortcomings. First, one would like to have detailed data on maturity. We cannot tell, for example, whether long-term debt is five-year or 30-year maturity. Dividing issues between short and all other maturities is still useful, however, given that most movement in the yield curve occurs between short and intermediate-and-longer maturities.

\footnotetext{
${ }^{6}$ The Flow of Funds data do not identify this retirement rate; the one-tenth assumption is chosen to be consistent with Guedes and Opler (1996), who report that the median maturity of debt issues is ten years in their sample. It might be possible to glean additional information about the appropriate retirement rate from the pattern of new issues. The intuition is that if there is a lump of long-term issues today, then when this debt retires, more of the change in long-term debt should be attributed to new issues. We attempted to incorporate this intuition and found that the adjusted series has a correlation of 0.94 with the simpler measure and does not change the basic results. We therefore report results for the simpler, unadjusted measure.
} 
Second, one would like data on floating rate features. Maturity and effective cost characteristics are usually directly related, but in the case of floating-rate debt, the relationship is blurred. A long-term floating rate issue, for example, has cost characteristics like short-term debt. One place where this distinction is important is in the Flow of Funds classification of bank loans as short-term debt. Although some of these loans undoubtedly have terms longer than one year, they are also frequently tied to floating rates (especially in the later half of the sample), so by cost characteristics they are short-term (as indicated in footnote (3) in the September 18, 2001 release of Table L.102, for example). Since our focus is on understanding variation in the maturity of new issues that is due to variation in relative cost characteristics, classifying bank loans as short-term does not seem inappropriate.

Third, one would like data on callability. A call provision reduces the effective maturity of an issue, and changes its cost characteristics accordingly. However, since call protection typically extends several years from the issue date, the cost of callable debt is likely to resemble that of straight debt for at least the first few years of the issue (the prediction horizon we consider). According to Van Horne (1984), longterm public issues before the late 1950 s were generally immediately callable. As the nominal targeting period passed and interest rate volatility increased, investors began to demand call protections. By the late 1960s, the majority of public issues had call protections of five or ten years.

We attempt to address these limitations of the data in robustness tests. We consider alternative assumptions about the retirement rate of long-term debt, and use other data sources to get a handle on the effect of trends in callability and floating rate features. ${ }^{7}$ Our exploration of Compustat data also addresses some limitations of the Flow of Funds data, but introduces limitations of its own. All things considered, we view the Flow of Funds long-term share variable as a rough but useful guide to broad trends in the maturity of debt issues.

Table 1 and Fig. 2 summarize these data. Panel A of Fig. 2 indicates that the scaled level of short-term debt issues has generally increased since 1953 but has fallen from its 1984 maximum. Panel B reveals no clear patterns in the level of long-term debt issues. Panel $\mathrm{C}$ shows that the long-term share in total debt issues has therefore declined slightly since 1953 but has rebounded in recent years. While the variation in the long-term share is not visibly dramatic, it is economically substantial. To illustrate this, note that the long-term share ranges between $14 \%$ (in 1990) and 29\% (in 1958). Total debt issues were $\$ 1.5$ trillion in 1990, so in order to move from $14 \%$ to $29 \%$, long-term debt issues in 1990 would have required a substitution of $\$ 225$ billion of short-term issues for long-term issues. Moreover, since the long-term share is defined using a one-year maturity breakpoint, it would not reveal a wholesale switch from 30-year to five-year issues, for example. On the other hand, the same

\footnotetext{
${ }^{7}$ Our data also do not contain information on interest rate swaps. This would not affect the information content of the long-term share variable before 1982, when the swaps market came into existence. After 1982, not accounting for swaps may reduce the information content of the aggregate long-term share to the extent that one counterparty is outside the sample (e.g., offshore). If both counterparties are in the sample, swaps have no net effect, since they do not reduce the aggregate exposure to interest rate fluctuations, they just redistribute it.
} 
Panel A. New issues of short-term debt $\left(d_{S t} / D_{t-1}\right)\left(\right.$ dash) and long-term debt $\left(d_{L t} / D_{t-1}\right)$ (solid)

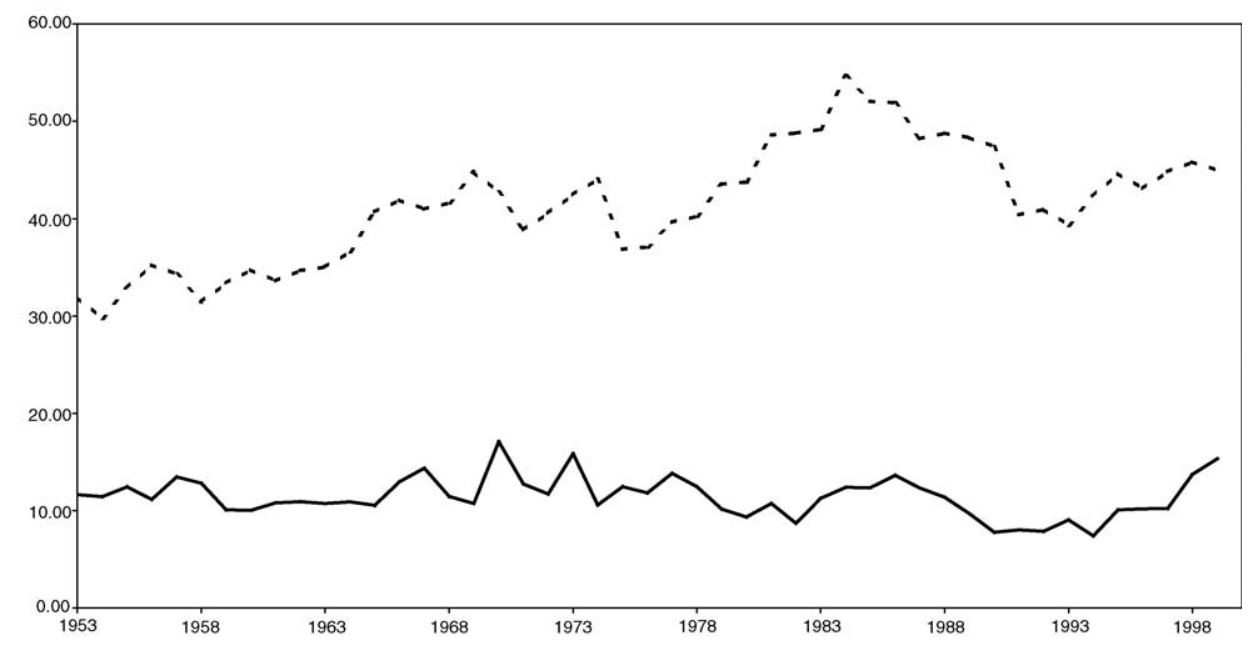

Panel B. Long-term share of debt issues $\left(d_{L t} /\left[d_{L t}+d_{S t}\right]\right)$ and NBER recessions (shaded)

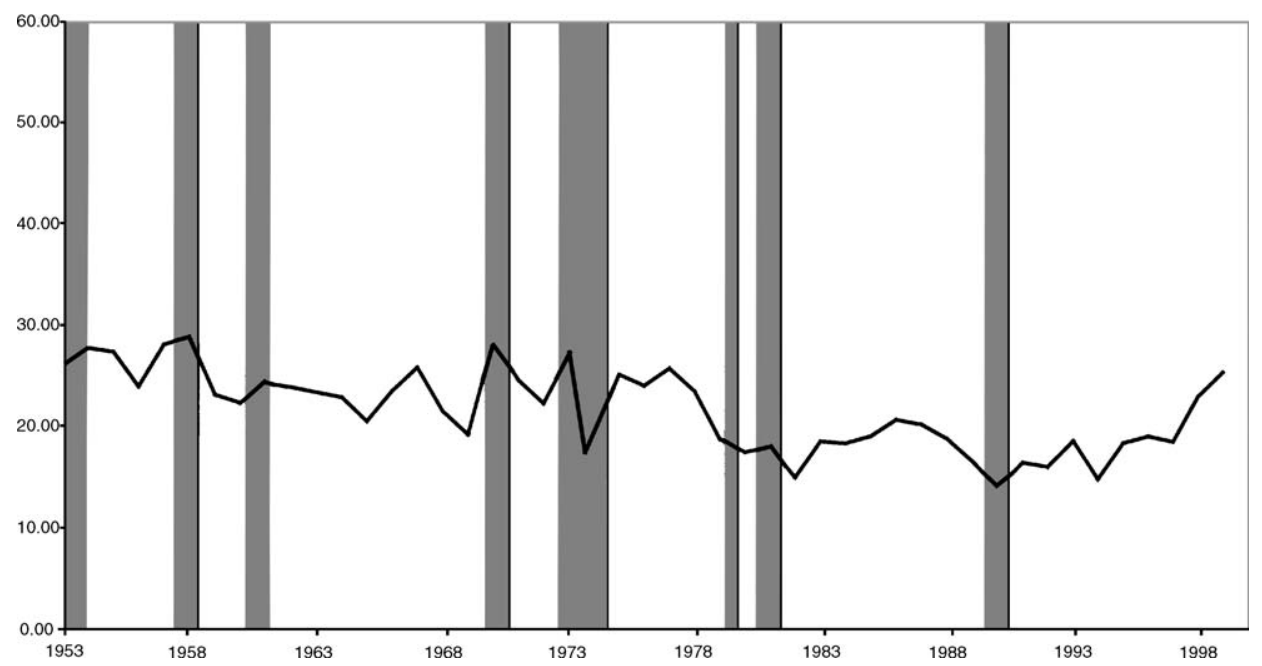

Fig. 2. The maturity of corporate debt issues: Federal Reserve Flow of Funds data. Long-term debt includes industrial revenue bonds, corporate bonds, and mortgages. Total debt also includes short-term debt, which is the sum of commercial paper, bank loans not elsewhere classified, and other short-term loans and advances. New short-term issues are defined as short-term debt outstanding. New long-term issues are defined as the change in long-term debt plus one-tenth of lagged long-term debt. Panel A shows short-term issues scaled by lagged total debt (dashed) and long-term issues scaled by lagged total debt (solid). Panel B shows the long-term share of total debt issues. All variables are expressed in percentage terms. 
logic suggests at least the possibility that when the long-term share does vary, the actual variation in maturity could be substantial.

Panel $\mathrm{C}$ also indicates NBER recessions as shaded areas, and reveals no visible business-cycle pattern in the long-term share. The average long-term share during recessions, broadly defined to include any calendar year that includes an NBER recession, was $22.5 \%$, and the average during expansions was $21.4 \%$. The difference is not statistically significant. The grand mean long-term share is $21.8 \%$, and the figure shows that the most recent values are slightly above this average.

\subsection{Market conditions and the maturity of debt issues}

In Table 3 we examine how debt market conditions affect the maturity of corporate debt issues. Panel A includes all debt market conditions measures, even those that do not predict excess bond returns, so as to be consistent with earlier tables. The specification in the first row is

$$
\begin{aligned}
\frac{d_{L t}}{d_{L t}+d_{S t}}= & a+b \pi_{t}+c\left(y_{G S t}-\pi_{t}\right)+d\left(y_{G L t}-y_{G S t}\right)+e\left(y_{C S t}-y_{G S t}\right) \\
& +f\left(\left(y_{C L t}-y_{G L t}\right)-\left(y_{C S t}-y_{G S t}\right)\right)+u_{t},
\end{aligned}
$$

where the inflation measure is expected inflation $\left(\pi_{E t}\right)$. Panel $\mathrm{B}$ uses actual inflation. As before, we standardize the independent variables but not the dependent variable.

The long-term share is negatively related to inflation, the real interest rate, and the term spread, and insignificantly related to the credit spread and the credit term spread. Market conditions also explain a large fraction of the time series variation in maturity. Note that this pattern of coefficients corresponds exactly to the pattern of coefficients in bond return predictive regressions from Eq. (1). Variables that enter positively there enter negatively here; variables that are insignificant there are also insignificant here. A natural interpretation is that firms borrow long when debt market conditions suggest that the relative cost of long-term debt is low. We outline other interpretations in the discussion section.

One way to verify that the maturity of debt issues responds to the same variation in market conditions that governs the relative cost of long-term borrowing is by using the fitted excess return from Table 2 as the lone regressor. The second specification in each panel uses this fitted return to explain variation in the long-term share:

$$
\frac{d_{L t}}{d_{L t}+d_{S t}}=a+g\left(\hat{R}_{G L t+3}-\hat{R}_{G S t+3}\right)+u_{t} .
$$

These regressions show more directly that the maturity of issues is sensitive to predictable variation in excess bond returns. Interestingly, the predicted excess bond return, by itself, explains nearly as much of the variation in the long-term share as do the five debt market variables when they are allowed to enter in an unrestricted way-in other words, the adjusted $R^{2}$ falls by less than 0.03 from the first to the second specification. 
Table 3

Debt market conditions and the maturity of corporate debt issues, Federal Reserve Flow of Funds data

OLS regressions of the long-term share of total debt issues $\left(d_{L} /\left[d_{L}+d_{S}\right]\right)$ on inflation $(\pi)$, the real short-term rate $\left(y_{G S}-\pi\right)$, the term spread $\left(y_{G L}-y_{G S}\right)$, the credit spread $\left(y_{C S}-y_{G S}\right)$, and the credit term spread $\left(\left(y_{C L}-y_{G L}\right)-\left(y_{C S}-y_{G S}\right)\right)$. We also consider the predicted excess long-term government bond return from Table 2 as an independent variable.

$$
\frac{d_{L t}}{d_{L t}+d_{S t}}=a+b \pi_{t}+c\left(y_{G S t}-\pi_{t}\right)+d\left(y_{G L t}-y_{G S t}\right)+e\left(y_{C S t}-y_{G S t}\right)+f\left(\left(y_{C L t}-y_{G L t}\right)-\left(y_{C S t}-y_{G S t}\right)\right)+g\left(\hat{R}_{G L t+3}-\hat{R}_{G S t+3}\right)+u_{t} .
$$

The long-term share is expressed in percentage terms and the independent variables are standardized to have unit variance. In Panel A, inflation is expected inflation $\left(\pi_{t}=\pi_{E t}\right)$. In Panel $\mathrm{B}$, inflation is actual inflation $\left(\pi_{t}=\pi_{A t}\right)$. $t$-statistics are heteroskedasticity robust and correct for time-series dependence up to three lags.

\begin{tabular}{|c|c|c|c|c|c|c|c|c|c|c|c|c|c|c|}
\hline \multirow[t]{2}{*}{$(\%)$} & \multirow[t]{2}{*}{$N$} & \multicolumn{2}{|c|}{$\pi_{t}$} & \multicolumn{2}{|c|}{$y_{G S t}-\pi_{t}$} & \multicolumn{2}{|c|}{$y_{G L t}-y_{G S t}$} & \multicolumn{2}{|c|}{$y_{C S t}-y_{G S t}$} & \multicolumn{2}{|c|}{$\left(y_{C L t}-y_{G L t}\right)-\left(y_{C S t}-y_{G S t}\right)$} & \multicolumn{2}{|c|}{$\hat{R}_{G L t+3}-\hat{R}_{G S t+3}$} & \multirow[t]{2}{*}{$R^{2}$} \\
\hline & & $b$ & {$[t]$} & $c$ & {$[t]$} & $d$ & {$[t]$} & $e$ & {$[t]$} & $f$ & {$[t]$} & $g$ & {$[t]$} & \\
\hline \multicolumn{15}{|c|}{ Panel A: The long-term share of total debt issues $\left(\pi_{t}=\pi_{E t}\right)$} \\
\hline$d_{L t} /\left[d_{L t}+d_{S t}\right]$ & 47 & -3.02 & {$[-4.53]$} & -2.68 & {$[-4.62]$} & -0.93 & {$[-1.51]$} & 0.00 & {$[0.00]$} & -0.46 & {$[-0.39]$} & & & 0.45 \\
\hline$d_{L t} /\left[d_{L t}+d_{S t}\right]$ & 47 & & & & & & & & & & & -2.42 & {$[-5.95]$} & 0.37 \\
\hline \multicolumn{15}{|c|}{ Panel B: The long-term share of total debt issues $\left(\pi_{t}=\pi_{A t}\right)$} \\
\hline$d_{L t} /\left[d_{L t}+d_{S t}\right]$ & 47 & & & & & & & & & & & -2.46 & {$[-5.95]$} & 0.38 \\
\hline
\end{tabular}




\subsection{Predicting excess bond returns from the maturity of debt issues}

These results naturally raise the question of whether the maturity of debt issues itself predicts excess bond returns. Fig. 3 divides the Flow of Funds long-term share into quartiles and tabulates it against one-year-ahead and cumulative three-yearahead excess returns. The figure confirms that there is a negative univariate relationship between the long-term share and subsequent excess returns. The threeyear cumulative excess government bond returns that follow a bottom-quartile share average 21.8 percentage points, while the returns following a top-quartile share average -5.2 percentage points. For corporate bond returns, the difference is 19.5 versus -4.9 , and the relationship across quartiles is monotonic. Note that predicted excess returns switch signs.

Table 4 investigates this predictive power more formally. The first row of Panel A, for example, reports two specifications:

$$
\begin{aligned}
& r_{G L t+1}-r_{G S t+1}=a+b_{1} \frac{d_{L t}}{D_{t-1}}+b_{2} \frac{d_{S t}}{D_{t-1}}+u_{t}, \\
& r_{G L t+1}-r_{G S t+1}=a+b \frac{d_{L t}}{d_{L t}+d_{S t}}+u_{t} .
\end{aligned}
$$

The results for Eq. (5a) indicate that long-term debt issues predict lower excess returns and short-term debt issues predict higher excess returns, as expected. While there appears to be useful information in both variables, the results for Eq. (5b) indicate that this information is effectively summarized in the long-term share in total debt issues. By itself, this variable is about as good a predictor as the combination of the levels $-R^{2}$ is similar for Eqs. (5b) and (5a). The long-term share is generally successful at predicting the excess return in each of the next three years, and consequently is successful at predicting the cumulative three-year-ahead return. ${ }^{8}$

One might ask whether debt issue decisions embody any incremental information over the set of debt market conditions we have been analyzing. This would in fact be surprising, given that firms do not have inside information about the course of interest rates, but they could also be responding to other public information besides the market conditions we consider. In the left columns of Table 5, we regress excess bond returns on debt issues and the predicted value of returns based on market conditions. For example, the regression in Column 2

\footnotetext{
${ }^{8}$ Whether the small-sample bias analyzed by Stambaugh (1999) affects these estimates is not obvious a priori. The long-term share is indeed highly autocorrelated, but there is no mechanical reason why its innovations would be correlated with innovations in excess bond returns. In fact, we find they are not correlated, so the correction suggested by Stambaugh does not materially affect the least-squares estimates. For one-year-ahead excess government returns, for example, the bias-corrected coefficient is -3.14 (unreported) compared to the least-squares coefficient of -3.18 .
} 
Panel A. Excess government bond returns (one-year-ahead returns - solid, cumulative three-year returns - hatch)

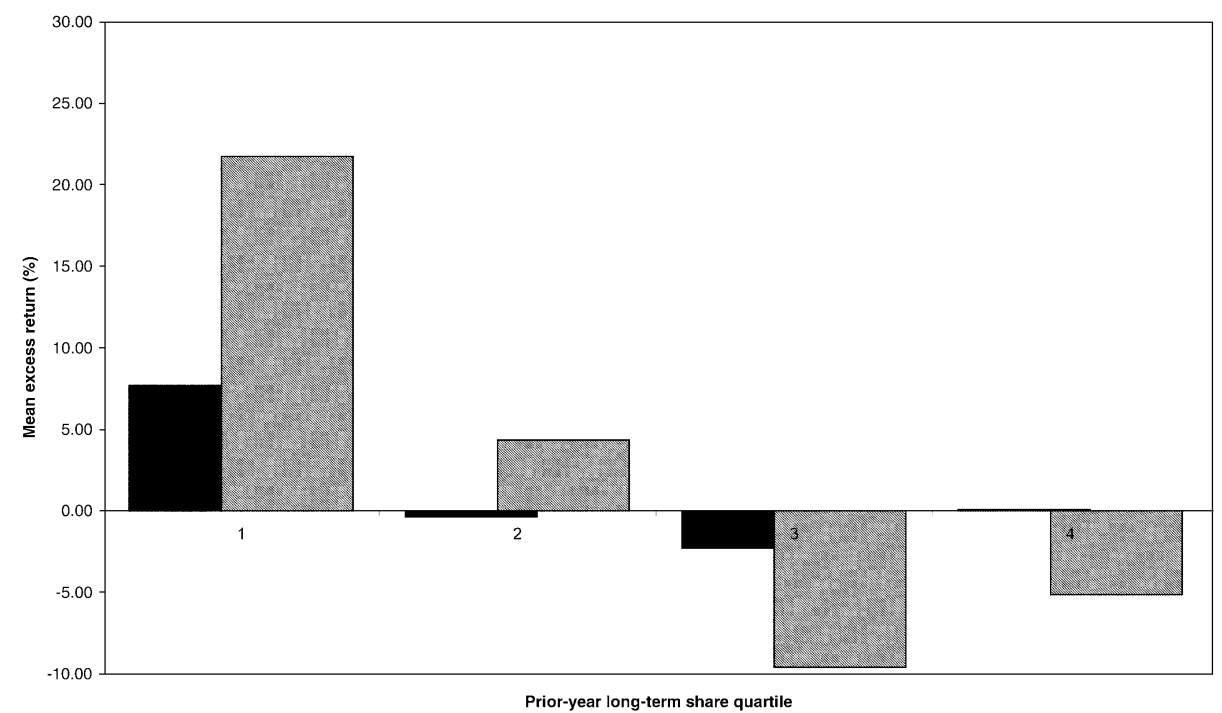

Panel B. Excess corporate bond returns (one-year-ahead returns - solid, cumulative three-year returns - hatch)

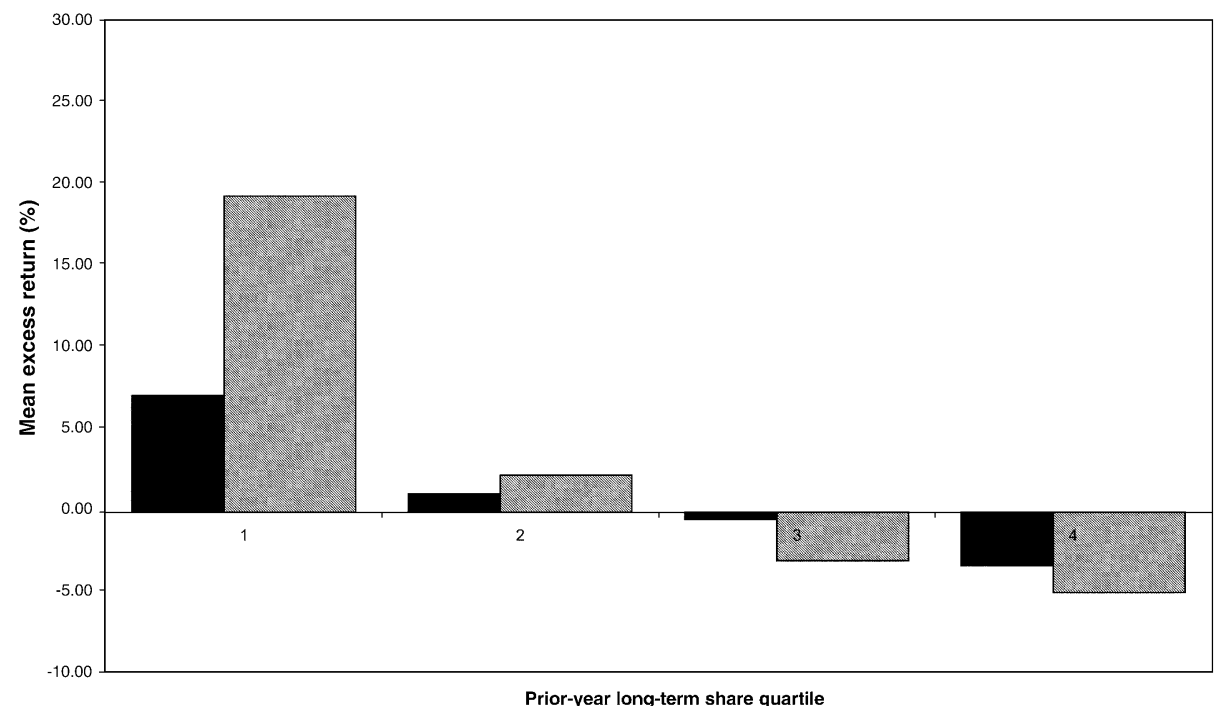

Fig. 3. The maturity of corporate debt issues and subsequent excess bond returns: Flow of Funds data. Excess government bond returns as predicted by the historical quartile of the prior year long-term share of total debt issues. Data on the maturity of corporate debt issues come from the Federal Reserve Flow of Funds. Panel A shows excess government bond returns. Panel B shows excess corporate bond returns. Excess bond returns are calculated for one-year-ahead (solid) and cumulative three-year-ahead (hatch) periods. 
Table 4

The maturity of corporate debt issues and excess bond returns, Federal Reserve Flow of Funds data OLS regressions predicting excess bond returns using the maturity of corporate debt issues [X]. The specification for predicting one-year-ahead excess government bond returns, for example, is

$$
r_{G L t+1}-r_{G S t+1}=a+\mathbf{b}^{\prime} \mathbf{X}_{t}+u_{t+1} \text {. }
$$

Excess bond returns are expressed in percentage terms. The independent variables are standardized to have unit variance. In Panel A, the dependent variable is the excess return on long-term government bonds over Treasury bills. In Panel B, the dependent variable is the excess return of corporate bonds over commercial paper. We predict one-year-ahead, two-year-ahead, and three-year-ahead returns $(r)$, and cumulative three-year-ahead returns $(R)$. We measure changes in the maturity structure as new issues of long-term debt $\left(d_{L} / D_{t-1}\right)$ controlling for new issues of short-term debt $\left(d_{S} / D_{t-1}\right)$ and as the longterm share of total new issues $\left(d_{L} /\left[d_{L}+d_{S}\right]\right)$. $t$-statistics are heteroskedasticity robust and correct for timeseries dependence up to three lags. The $F$-test reports the joint significance level of $\left(d_{L} / D_{t-1}\right)$ and $\left(d_{S} / D_{t-1}\right)$.

\begin{tabular}{|c|c|c|c|c|c|c|c|c|c|c|c|}
\hline \multirow[b]{2}{*}{$(\%)$} & \multirow[b]{2}{*}{$N$} & \multicolumn{2}{|c|}{$d_{L t} / D_{t-1}$} & \multicolumn{2}{|c|}{$d_{S t} / D_{t-1}$} & \multirow[b]{2}{*}[F]{} & \multirow[b]{2}{*}{$R^{2}$} & \multirow[b]{2}{*}{$N$} & \multicolumn{2}{|c|}{$d_{L t} /\left[d_{L t}+d_{S t}\right]$} & \multirow[b]{2}{*}{$R^{2}$} \\
\hline & & $b_{1}$ & {$[t]$} & $b_{2}$ & {$[t]$} & & & & $b$ & {$[t]$} & \\
\hline \multicolumn{12}{|c|}{ Panel A: Excess government bond returns } \\
\hline$r_{G L t+1}-r_{G S t+1}$ & 47 & -1.83 & {$[-1.29]$} & 2.82 & {$[2.60]$} & {$[0.01]$} & 0.11 & 47 & -3.18 & {$[-2.99]$} & 0.10 \\
\hline$r_{G L t+2}-r_{G S t+2}$ & 46 & -1.62 & {$[-1.52]$} & 2.89 & {$[2.97]$} & {$[0.01]$} & 0.11 & 46 & -3.06 & {$[-2.78]$} & 0.09 \\
\hline$r_{G L t+3}-r_{G S t+3}$ & 45 & -2.65 & {$[-1.97]$} & 3.26 & {$[3.21]$} & {$[0.00]$} & 0.17 & 45 & -4.07 & {$[-3.15]$} & 0.15 \\
\hline$R_{G L t+3}-R_{G S t+3}$ & 45 & -6.47 & {$[-2.91]$} & 8.86 & {$[3.98]$} & {$[0.00]$} & 0.43 & 45 & -10.47 & {$[-4.90]$} & 0.39 \\
\hline \multicolumn{12}{|c|}{ Panel B: Excess corporate bond returns } \\
\hline$r_{G L t+1}-r_{G S t+1}$ & 47 & -2.32 & {$[-2.13]$} & 2.59 & {$[2.31]$} & {$[0.00]$} & 0.13 & 47 & -3.31 & {$[-3.93]$} & 0.12 \\
\hline$r_{G L t+2}-r_{G S t+2}$ & 46 & -1.79 & {$[-1.60]$} & 2.74 & {$[2.96]$} & {$[0.01]$} & 0.12 & 46 & -3.10 & {$[-2.83]$} & 0.10 \\
\hline$r_{G L t+3}-r_{G S t+3}$ & 45 & -2.31 & {$[-1.65]$} & 3.00 & {$[2.76]$} & {$[0.02]$} & 0.15 & 45 & -3.65 & {$[-2.68]$} & 0.14 \\
\hline$R_{G L t+3}-R_{G S t+3}$ & 45 & -6.40 & {$[-3.35]$} & 8.43 & {$[3.55]$} & {$[0.00]$} & 0.41 & 45 & -10.08 & {$[-4.71]$} & 0.36 \\
\hline
\end{tabular}

of Panel A is

$$
r_{G L t+1}-r_{G S t+1}=a+b \frac{d_{L t}}{d_{L t}+d_{S t}}+c\left(\hat{R}_{G L t+k}-\hat{R}_{G S+k}\right)+u_{t+1}
$$

For one-year-ahead excess returns, debt issue maturity does not add much to the predictability based on market conditions. In Panel A for example, the long-term share is insignificant and the regression has an $R^{2}$ of 0.26 in Column 2. Column 1 shows that without the long-term share, market conditions alone provide an $R^{2}$ of 0.25. There is some evidence of incremental predictive power for three-year cumulative returns.

Most bond market research focuses exclusively on the term spread, so one may be interested to know whether the long-term share adds predictive power to this variable alone. The right columns of Table 5 indicate that the long-term share does indeed add significant predictive power to the term spread, even at the one-year horizon. The important insight from these results is not whether the predictive power 
Table 5

The maturity of corporate debt issues, debt market conditions, and excess bond returns, Federal Reserve Flow of Funds data

OLS regressions predicting excess bond returns using the long-term share of total debt issues and debt market conditions. The general specification for predicting one-year-ahead excess government bond returns, for example, is

$$
r_{G L t+1}-r_{G S t+1}=a+b \frac{d_{L t}}{d_{L t}+d_{S t}}+c\left(\hat{R}_{L t+1}-\hat{R}_{S t+1}\right)+d\left(y_{G L t}-y_{G S t}\right)+u_{t+1} .
$$

Excess bond returns are expressed in percentage terms. The independent variables are standardized to have unit variance. In Panel A, the dependent variable is the excess return on long-term government bonds over Treasury bills. In Panel B, the dependent variable is the excess return of corporate bonds over commercial paper. We predict one-year-ahead and cumulative three-year-ahead returns. We control for debt market conditions in two ways. In the first four columns, we include the predicted excess long-term government bond return from Table 2. In the second four columns, we include the term spread. $t$-statistics in brackets are heteroskedasticity robust and correct for time-series dependence up to three lags.

\begin{tabular}{|c|c|c|c|c|c|c|c|c|}
\hline & \multicolumn{4}{|c|}{ Increment over forecast return } & \multicolumn{4}{|c|}{ Increment over term spread } \\
\hline & \multicolumn{2}{|c|}{ 1-year return } & \multicolumn{2}{|c|}{ Cum. 3-year return } & \multicolumn{2}{|c|}{ 1-year return } & \multicolumn{2}{|c|}{ Cum. 3-year return } \\
\hline & (1) & (2) & (3) & (4) & $(5)$ & (6) & (7) & (8) \\
\hline \multicolumn{9}{|c|}{ Panel A: Excess government bond returns } \\
\hline$d_{L t} /\left[d_{L t}+d_{S t}\right]$ & & $\begin{array}{r}-0.94 \\
{[-0.77]}\end{array}$ & & $\begin{array}{r}-6.12 \\
{[-2.52]}\end{array}$ & & $\begin{array}{r}-2.84 \\
{[-3.52]}\end{array}$ & & $\begin{array}{l}-10.11 \\
{[-4.90]}\end{array}$ \\
\hline$\hat{R}_{G L t+k}-\hat{R}_{G S t+k}$ & $\begin{array}{r}5.14 \\
{[5.52]}\end{array}$ & $\begin{array}{r}4.70 \\
{[3.95]}\end{array}$ & $\begin{array}{l}10.70 \\
{[6.64]}\end{array}$ & $\begin{array}{r}6.92 \\
{[3.65]}\end{array}$ & & & & \\
\hline$y_{G L t}-y_{G S t}$ & & & & & $\begin{array}{r}3.60 \\
{[4.73]}\end{array}$ & $\begin{array}{r}3.36 \\
{[3.70]}\end{array}$ & $\begin{array}{r}4.18 \\
{[1.83]}\end{array}$ & $\begin{array}{r}3.32 \\
{[2.08]}\end{array}$ \\
\hline$N$ & 47 & 47 & 45 & 45 & 47 & 47 & 45 & 45 \\
\hline$R^{2}$ & 0.25 & 0.26 & 0.41 & 0.49 & 0.15 & 0.23 & 0.08 & 0.43 \\
\hline \multicolumn{9}{|c|}{ Panel B: Excess corporate bond returns } \\
\hline$d_{L t} /\left[d_{L t}+d_{S t}\right]$ & & $\begin{array}{r}-1.14 \\
{[-1.08]}\end{array}$ & & $\begin{array}{r}-5.66 \\
{[-2.65]}\end{array}$ & & $\begin{array}{r}-2.94 \\
{[-5.19]}\end{array}$ & & $\begin{array}{r}-9.77 \\
{[-4.60]}\end{array}$ \\
\hline$\hat{R}_{C L t+k}-\hat{R}_{C S t+k}$ & $\begin{array}{r}5.30 \\
{[5.27]}\end{array}$ & $\begin{array}{r}4.79 \\
{[3.34]}\end{array}$ & $\begin{array}{l}10.58 \\
{[6.15]}\end{array}$ & $\begin{array}{r}7.13 \\
{[3.26]}\end{array}$ & & & & \\
\hline$y_{G L t}-y_{G S t}$ & & & & & $\begin{array}{r}3.82 \\
{[4.09]}\end{array}$ & $\begin{array}{r}3.57 \\
{[3.11]}\end{array}$ & $\begin{array}{r}3.68 \\
{[1.66]}\end{array}$ & $\begin{array}{r}2.85 \\
{[1.59]}\end{array}$ \\
\hline$N$ & 47 & 47 & 45 & 45 & 47 & 47 & 45 & 45 \\
\hline$R^{2}$ & 0.30 & 0.31 & 0.41 & 0.48 & 0.19 & 0.29 & 0.06 & 0.40 \\
\hline
\end{tabular}

of the long-term share is greater than that of any other variable, but that its predictive ability appears to reflect its connection to market conditions.

\subsection{Robustness of the Flow of Funds results}

In Table 6 we examine several robustness issues. For reference, the first row repeats the baseline predictability results from Table 4 . The next two rows address 
Table 6

Robustness tests, Federal Reserve Flow of Funds data

OLS regressions predicting excess bond returns using the long-term share of total debt issues. The specification for predicting one-year-ahead excess government bond returns, for example, is

$$
r_{G L t+1}-r_{G S t+1}=a+b \frac{d_{L t}}{d_{L t}+d_{S t}}+u_{t+1} .
$$

Excess bond returns are expressed in percentage terms. The independent variable is standardized to have unit variance. In Panel A, the dependent variable is the excess return on long-term government bonds. In Panel $\mathrm{B}$, the dependent variable is the excess return of corporate bonds over commercial paper. We examine aspects of robustness by (1) adjusting for floating rate and callable long-term debt, (2) varying the sample period, and (3) varying the assumed retirement rate of long-term debt. $t$-statistics are heteroskedasticity robust and correct for time-series dependence up to three lags. The $F$-test reports the joint significance level of $\left(d_{L} / D_{t-1}\right)$ and $\left(d_{S} / D_{t-1}\right)$.

\begin{tabular}{|c|c|c|c|c|c|c|c|c|}
\hline \multirow[t]{3}{*}{ Adjustment } & \multicolumn{4}{|c|}{ 1-year return } & \multicolumn{4}{|c|}{ Cum. 3-year return } \\
\hline & \multirow[b]{2}{*}{$N$} & \multicolumn{2}{|c|}{$d_{L t} /\left[d_{L t}+d_{S t}\right]$} & \multirow[b]{2}{*}{$R^{2}$} & \multirow[b]{2}{*}{$N$} & \multicolumn{2}{|c|}{$d_{L t} /\left[d_{L t}+d_{S t}\right]$} & \multirow[b]{2}{*}{$R^{2}$} \\
\hline & & $b$ & {$[t]$} & & & $b$ & {$[t]$} & \\
\hline \multicolumn{9}{|c|}{ Panel A: Excess government bond returns } \\
\hline Unadjusted & 47 & -3.18 & {$[-2.99]$} & 0.10 & 45 & -10.47 & {$[-4.90]$} & 0.39 \\
\hline Float adjusted & 47 & -3.63 & {$[-3.34]$} & 0.12 & 45 & -10.96 & {$[-5.24]$} & 0.43 \\
\hline Call adjusted & 47 & -2.86 & {$[-2.83]$} & 0.08 & 45 & -10.41 & {$[-5.28]$} & 0.36 \\
\hline 1954-1976 & 23 & -0.72 & {$[-0.40]$} & 0.01 & 23 & -1.15 & {$[-0.37]$} & 0.01 \\
\hline 1977-2000 & 24 & -5.32 & {$[-2.16]$} & 0.11 & 22 & -21.24 & {$[-8.05]$} & 0.61 \\
\hline Retirement rate $=1 / 5$ & 47 & -3.30 & {$[-3.41]$} & 0.10 & 45 & -10.72 & {$[-4.64]$} & 0.41 \\
\hline Retirement rate $=1 / 20$ & 47 & -2.93 & {$[-2.43]$} & 0.08 & 45 & -9.80 & {$[-4.61]$} & 0.33 \\
\hline \multicolumn{9}{|c|}{ Panel B: Excess corporate bond returns } \\
\hline Unadjusted & 47 & -3.31 & {$[-3.93]$} & 0.12 & 45 & -10.08 & {$[-4.71]$} & 0.36 \\
\hline Float adjusted & 47 & -3.61 & {$[-4.50]$} & 0.14 & 45 & -10.55 & [-4.84] & 0.40 \\
\hline Call adjusted & 47 & -2.97 & {$[-3.09]$} & 0.10 & 45 & -10.33 & {$[-5.40]$} & 0.36 \\
\hline 1954-1976 & 23 & -1.83 & {$[-1.04]$} & 0.03 & 23 & -2.99 & {$[-0.91]$} & 0.04 \\
\hline $1977-2000$ & 24 & -5.87 & {$[-3.64]$} & 0.17 & 22 & -21.59 & {$[-7.79]$} & 0.62 \\
\hline Retirement rate $=1 / 5$ & 47 & -3.33 & {$[-3.80]$} & 0.12 & 45 & -10.23 & {$[-4.28]$} & 0.38 \\
\hline Retirement rate $=1 / 20$ & 47 & -3.13 & {$[-3.50]$} & 0.11 & 45 & -9.52 & {$[-4.65]$} & 0.32 \\
\hline
\end{tabular}

the lack of information on floating rate and call provisions. Using Compustat, we construct a short time series (1976 through 1999) of the fraction of long-term debt outstanding that is tied to a floating interest rate. We also construct a short time series (1976 through 2000) of the fraction of long-term debt issues with call provisions using data from the Securities Data Corporation. The Flow of Funds longterm share is uncorrelated with the fraction of long-term debt linked to the prime rate and has a correlation of -0.49 with the fraction of callable debt. In other words, when firms issue a relatively high share of short-term debt, the long-term debt that they issue is more likely to be callable - more like short-term debt in terms of its effective cost - than is normally the case. Also interesting and consistent with the 
message of Table 4, the fraction of long-term debt linked to prime, which has the same cost characteristics as straight short-term debt, is itself positively correlated with future bond returns (unreported).

As mentioned before, the forecasting power of the long-term share is likely to be particularly diminished by counting long-term floating rate debt alongside long-term fixed rate debt; issuing floating rate debt suggests an expectation that the relative cost of long-term debt is high, not low. Using these series, we make an adjustment to remove long-term callable issues from all debt issues and reclassify long-term debt linked to prime as effectively short-term. These adjustments do not make much difference.

The next two rows examine the stability of the relationships over time. We split the sample into halves (1954-1976, 1977-2000). The long-term share is significant and large within the later half but not the earlier half. Note that the earlier half also corresponds to much lower volatility in inflation, the term spread, and excess bond returns (see Fig. 1), so there may not be enough predictable variation in excess returns in this period to induce informative adjustments in debt maturity. Consistent with this explanation, the predictive power of the term spread is similarly unstable. A univariate predictive regression using the term spread has an $R^{2}$ of only 0.01 for oneyear returns or three-year cumulative returns in the earlier half of the sample, and for three-year cumulative returns the coefficient is actually negative. ${ }^{9}$ One potential interpretation is that, only to the extent that market conditions are informative about future excess returns, the maturity of debt issues responds in proportion.

The last two rows examine our assumption that one-tenth of long-term debt is retired each year. Alternative assumptions that the retirement rate is instead one-fifth or one-twentieth give similar results. Finally, we have examined the effect of removing individual years of data, and found that no single year of data drives the results.

\section{Debt issue maturity and the relative cost of long-term debt: Compustat sample}

In this section we explore a second data source for corporate debt issues. We generate time series from aggregations of Compustat firm-level data. To the extent that the basic results line up with the Flow of Funds results, they reinforce our previous robustness tests. Also, by varying the set of firms included in the aggregations, we can examine whether there are any revealing cross-sectional differences.

\subsection{Compustat debt issues data}

We calculate aggregate debt issues for various subsets of Compustat firms between 1976 and 1999. While Compustat has some coverage back to 1954, the early data unfortunately cannot be used because only a small percentage of firm-years contain

\footnotetext{
${ }^{9}$ Scatterplots that illustrate these features are available upon request.
} 
the required data. ${ }^{10}$ Thus the primary disadvantage of Compustat vis-à-vis Flow of Funds is its shorter coverage.

We define Compustat short-term debt issues as notes payable (Item 206). Compustat long-term debt issues are the change in the level of long-term debt (Item 9) plus debt due in one year (Item 44). To be included in the aggregations, a Compustat firm-year observation must have nonmissing debt data in both year $t$ and $t-1$. We then sum short- and long-term debt issues across firms and construct the long-term share $\left(d_{L t} /\left[d_{L t}+d_{S t}\right]\right)$ as before. In 1976 , the first year of our sample, the aggregations include up to 6,084 security identifiers (CUSIPs), and this upper limit grows steadily to a peak of 10,345 in 1996, then declines to 9,930 in 1999.

Over the 1976-1999 period for which they overlap, the Compustat series long-term share is generally higher than the Flow of Funds series, possibly because Compustat firms have better access to long-term debt markets than does the average firm. At an annual frequency the two series have a correlation of $0.50 .^{11}$

\subsection{Issue maturity, the term spread, and bond return predictability: Compustat splits}

With only 25 data points in the Compustat long-term share series, we are limited to studying univariate relationships in Table 7. Panel A reports the relationship between the Compustat share and the term spread. Panel B reports the predictive power of the long-term share for one-year-ahead excess government bond returns. The first row in each panel reports results for the long-term share calculated by aggregating across all Compustat firms with usable data. The basic results echo the Flow of Funds results: Compustat firms send to favor long-term debt when the term spread is low and when future excess bond returns are low. ${ }^{12}$

The advantage of Compustat data is that it allows us to construct the long-term share on specific cross-sectional dimensions. What type of firm is more likely to make debt maturity decisions based on market conditions? One plausible source of cross-sectional variation is differences in access to the maturity spectrum. Small, young firms of low credit quality may be simply unable to issue long-term debt, while

\footnotetext{
${ }^{10}$ Specifically, the percentage of firms covered by Compustat with nonmissing debt issues data starts at about $25 \%$ in 1955 and does not level out at around $90 \%$ until 1976. This alone would not cause a bias, but there is a pronounced tendency for the nonmissing observations to take on zero values. In 1960, for instance, only four of the 86 firms with nonmissing debt issues data actually have nonzero notes payable; the other 82 are zero. The percentage of firms with nonmissing and nonzero notes payable increases steadily throughout the early years of the sample. Our best explanation for these patterns is that in early balance sheet data, it is very common for notes payable and the current portion of long-term debt to be combined. Compustat breaks down these values separately (which we require) only when it can confidently do so. Most commonly, in the early years, this happens when the reported total is zero. When the total is zero, Compustat can correctly infer that both of the components are zero. This explains why the nonmissing observations on notes payable are mostly zero in the early data. As balance sheets have become more detailed over time, this problem has been attenuated.

${ }^{11}$ A figure comparing the Flow of Funds and Compustat time series is available upon request.

${ }^{12}$ In unreported results, we also find that the Compustat long-term share does not have incremental predictive power over the term spread at the one-year horizon. This differs from our conclusion using Flow of Funds data.
} 
Table 7

The maturity of corporate debt issues, the term spread, and excess bond returns, Compustat data Panel A shows OLS regressions explaining the Compustat long-term share in total debt issues with the term spread. Panel B shows OLS regressions predicting one-year-ahead excess government bond returns using the Compustat long-term share in total debt issues.

$$
\text { Panel A : } \frac{d_{L t}}{d_{L t}+d_{S t}}=a+b\left(y_{G L t}-y_{G S t}\right)+u_{t} \text {, Panel B : } r_{G L t+1}-r_{G S t+1}=a+b \frac{d_{L t}}{d_{L t}+d_{S t}}+u_{t+1} \text {, }
$$

Excess bond returns are expressed in percentage terms. The independent variables are standardized to have unit variance. Debt issues data are firm-by-firm aggregations from Compustat. The firms included in each aggregation are determined as follows: old firms are those that have Compustat data going back more than five years; high credit quality firms have an investment grade rating from S\&P in Compustat (note this is a current, not historical debt rating); high market capitalization firms are those that fall above the NYSE median (breakpoints provided by Ken French); dividend payers pay nonzero common dividends (Item 21). $t$-statistics are heteroskedasticity robust and correct for time-series dependence up to three lags.

Panel A: Compustat long-term share on the term spread

\begin{tabular}{|c|c|c|c|c|c|c|c|c|}
\hline & & $y_{G L t}$ & $-y_{G S t}$ & & & $y_{G L t}$ & $-y_{G S t}$ & \\
\hline & $N$ & $b$ & {$[t]$} & $R^{2}$ & $N$ & $b$ & {$[t]$} & $R^{2}$ \\
\hline All firms & 25 & -2.91 & {$[-4.59]$} & 0.29 & & & & \\
\hline Old firms ( $>5$ years $)$ & 25 & -4.02 & {$[-4.16]$} & 0.26 Young firms ( $\leqslant 5$ years) & 25 & 0.52 & {$[0.51]$} & 0.01 \\
\hline High credit quality & 25 & -2.90 & {$[-4.84]$} & 0.28 Low credit quality & 25 & -2.51 & {$[-2.55]$} & 0.15 \\
\hline High market capitalization & 25 & -4.06 & {$[-4.23]$} & 0.25 Low market capitalization & 25 & -1.31 & {$[-2.33]$} & 0.13 \\
\hline Dividend payers & 25 & -2.77 & {$[-3.71]$} & 0.21 Nonpayers & 25 & -4.51 & {$[-2.50]$} & 0.12 \\
\hline
\end{tabular}

Panel B: One-year-ahead excess government bond returns on the Compustat long-term share

\begin{tabular}{|c|c|c|c|c|c|c|c|c|}
\hline \multirow{2}{*}{\multicolumn{2}{|c|}{$N$}} & \multicolumn{2}{|c|}{$\underline{d_{L t} /\left[d_{L t}+d_{S t}\right]}$} & \multirow[b]{2}{*}{$R^{2}$} & \multirow[b]{2}{*}{$N$} & \multicolumn{2}{|c|}{$d_{L t} /\left[d_{L t}+d_{S t}\right]$} & \multirow[b]{2}{*}{$R^{2}$} \\
\hline & & $b$ & {$[t]$} & & & $b$ & {$[t]$} & \\
\hline All firms & 24 & -10.98 & {$[-2.57]$} & 0.13 & & & & \\
\hline Old firms ( $>5$ years) & 24 & -8.84 & {$[-4.13]$} & 0.20 Young firms ( $\leqslant 5$ years $)$ & 24 & 5.78 & {$[0.80]$} & 0.05 \\
\hline High credit quality & 24 & -11.58 & {$[-2.65]$} & 0.15 Low credit quality & 24 & -4.85 & {$[-0.77]$} & 0.02 \\
\hline High market capitalization & 24 & -9.67 & {$[-3.19]$} & 0.16 Low market capitalization & 24 & 0.13 & [0.03] & 0.00 \\
\hline Dividend payers & 24 & -10.98 & {$[-2.94]$} & 0.15 Nonpayers & 24 & 0.09 & {$[0.04]$} & 0.00 \\
\hline
\end{tabular}

established and more stable firms have more flexibility. Consistent with this intuition, Guedes and Opler (1996) find that very long-term borrowing is concentrated among large firms with investment grade credit ratings. In addition, Graham and Harvey (2001) find that the CFOs of large-cap and dividend-paying firms are more likely to state that they attempt to time Treasury rates. ${ }^{13}$

\footnotetext{
${ }^{13}$ Specifically, Graham and Harvey ask three questions related to debt market timing: to paraphrase, they are "Do you issue debt when interest rates are particularly low?"; "Do you prefer short-term debt when short-term interest rates are low compared to long-term rates?"; and "Do you prefer short-term debt when waiting for long-term market interest rates to decline?" CFOs of large capitalization firms, dividend paying firms, and public firms were more likely to give a strong or very strong "yes" answer to each of these questions. Since all Compustat firms are publicly traded, we split the sample by capitalization and dividend-paying status.
} 
We split the Compustat data in several ways in order to test these patterns. The results in Table 7 are generally consistent with the hypothesized relations. Panel A shows that large, old, creditworthy, and dividend-paying firms align their long-term share more closely to the term spread. The results on size and dividend-paying status match up directly with the survey findings, and the results on credit quality are consistent with the results of Guedes and Opler. Panel B shows that these same firms' maturity decisions have particularly high predictive power for future excess bond returns. These cross-sectional patterns complement and generally reinforce the Flow of Funds sample results.

\section{Discussion}

The evidence that corporate debt maturity is closely tied to predictable variation in excess bond returns adds a stylized fact to corporate finance. It also raises two fundamental questions. Does the predictable variation reflect market inefficiency or segmentation? And do firms reduce their overall cost of capital by substituting across maturities in the observed manner?

The Modigliani-Miller theorem shows that these two questions are equivalent. In efficient, integrated, and otherwise perfect markets, the theorem fixes the overall cost of capital in proportion to cash flow risk alone. For example, consider a firm with a fixed ratio of total debt to equity. The cash flow risk of the firm is shared by its equity and short- and long-term debt holders. The only way to reduce the average cost of the "portfolio" of short- and long-term debt is to increase the risk of the cash flows to equity holders, thus increasing the cost of equity. The bottom line is that the costs of different forms of capital do not vary independently in efficient and integrated markets, so the overall cost of capital cannot be reduced. In inefficient or segmented markets, by contrast, the MM theorem does not apply, and market timing-defined generally as raising finance in whatever form is currently available at the lowest riskadjusted cost - can in those circumstances reduce the overall cost of capital.

This suggests three general explanations for our results.

Explanation (1): Rational managers, rational investors. The debt market is efficient and integrated with the equity market. Debt issues are linked to time-varying excess bond returns because optimal debt maturity structure is related to excess bond returns.

Explanation (2): Rational managers, irrational investors. Managers successfully time an inefficient debt market.

Explanation (3): Irrational managers, rational investors. Managers try in vain to time an efficient debt market.

In the first explanation, manipulating the maturity does not (and is not intended to) reduce the cost of capital. Excess bond returns and optimal debt maturity structure are connected behind the scenes. In the second, the predictability of excess bond returns that we observe is attributed to inefficiency, at least in part, and managers are reducing the overall cost of capital by adjusting debt maturity in 
response. In the third explanation, managers try their hand at debt market timing but are unsuccessful. Perhaps rules of thumb such as "issue short-term when the yield curve is steep" simply redistribute overall cash flow risk across securities in a way that they do not recognize, but investors do, and so the overall cost of capital is not reduced. As we discuss below, we conclude that managers are almost surely trying to time the debt market, but despite suggestive evidence it is hard to prove that their efforts reduce the overall cost of capital. Thus we favor (2) or (3) over (1).

\subsection{Debt market efficiency and integration with the equity market}

Explanations (1) and (3) both maintain that the predictive power of the long-term share reflects an efficient and integrated debt market. We examine this difficult question here. We do not develop theories of debt market inefficiency per se. Prior work on bond investor sentiment includes Modigliani and Sutch (1966a,b) and Shiller (1996), who argue that investors have time-varying preferences for short- and long-term debt, and Shiller et al. (1983), who argue that long-term rates overreact to information more relevant to short-term rates. The survey evidence in Froot (1989) also suggests that bond investors do not have unbiased expectations about changes in interest rates.

In an efficient debt market, the long-term share is inversely related to future returns because it is inversely related to time-varying risk. Covariance with consumption is the only risk factor in Breeden (1979), and Lettau and Ludvigson (2001) argue for the empirical validity of the consumption-based paradigm. In unreported results (available upon request), we examine whether the long-term share is inversely related to consumption covariance. Specifically, we use the methodology of Duffee (2001) to test whether the Flow of Funds long-term share predicts a lower covariance of excess bond returns with consumption growth. The relationship turns out to be weak and of the wrong sign.

A second possibility is that the long-term share is connected to variance risk. Breeden (1986) derives a relationship between expected excess bond returns and the conditional variance of consumption. The intertemporal CAPM of Merton (1973) and the Asset Pricing Theory of Ross (1976) admit multiple risk factors, and in some implementations the risk premia are specified as related to the conditional variances of underlying state variables (e.g., French et al., 1987). Several studies have attempted to connect predictor variables to future variance risks. In unreported results (available upon request), we follow Schwert (1989) and test whether the longterm share predicts the standard deviation of conditional consumption growth or conditional excess bond returns. The results are mixed. The long-term share is indeed negatively related to future excess bond return variance but is marginally positively related to future consumption variance. The former result is in the right direction for a risk-based explanation, but the magnitude appears too small to account for large return predictability effects. (A one-standard-deviation increase in the long-term share reduces one-year-ahead excess returns by more than it reduces their standard deviation, indicating a Sharpe ratio above one.) 
Finally, debt market timing could reduce the overall cost of capital if the debt and equity markets are not perfectly integrated. Consider two firms with the same cash flow risk and the same leverage. One firm switches between short- and long-term debt following the historical pattern of the long-term share. The other uses long-term debt exclusively. Ex post, the predictability results show that the first firm has paid less for its debt. The MM theorem says that it must have paid commensurately more for its equity, if markets are efficient and integrated, since equity would have to absorb the cash flow risk allegedly responsible for the time-varying term premium. One testable implication of this logic is that the long-term share should predict the cost of equity in the same direction as the relative cost of long-term debt. In unreported regressions of excess stock market returns on the Flow of Funds longterm share, we find that the coefficients are small and statistically insignificant.

\subsection{Optimal debt maturity structure}

Explanation (1) also maintains that debt issues are related to future excess returns because optimal debt maturity is connected to future excess returns. This is another angle on this explanation that we can explore.

Perhaps surprisingly, only one theory of optimal debt maturity directly involves interest rates: the tax theory developed by Brick and Ravid $(1985,1991)$ and outlined in Gordon (1982). In this theory, managers accelerate tax deductions by issuing more long-term debt when long-term rates are relatively high or, under a convex tax schedule, when interest rates are particularly volatile. Tables 3 and 7 and the unreported results described in the previous subsection, however, are opposite to this prediction. Firms issue more long-term debt when the term structure is flat and future interest rates are stable. The firm-level results in Barclay and Smith (1995), Guedes and Opler (1996), and Stohs and Mauer (1996) also contradict the tax theory.

It is possible to construct ad hoc stories to connect our predictability results to optimal maturity theories without directly involving debt market conditions. One such story involves debt overhang and time-varying business conditions. Myers (1977) notes that an overhang of long-term debt can force firms to forgo positive net present value investments that require new capital. To avoid this, firms with more growth opportunities should prefer short-term debt. If growth opportunities vary over time, the long-term share would then vary inversely. This theory does not directly connect to subsequent bond returns, but Fama and French (1989) suggest that expected excess bond returns are generally low when business conditions are good - which is perhaps when growth opportunities are good and, according to the debt overhang theory, when the long-term share should be low. This story appears to predict a positive relationship between the long-term share and subsequent excess bond returns, not the negative relationship that we observe. Furthermore, as Fig. 2 suggests, the NBER measure of business cycles is unconnected with the Flow of Funds long-term share variable.

Another possible explanation involves time-varying liquidity risk. Diamond (1991) and Rajan (1992) note that short-term debt may be difficult to refinance, leading to 
costly financial distress. This suggests that when liquidity risk is higher, the preference for long-term debt will be higher. These models do not directly involve interest rate risk. If one equates liquidity risk with interest rate risk, however, these models tend to predict that when interest rate risk is high, corporations prefer longterm debt. This is opposite to the evidence.

Yet another story involves liquidity itself as opposed to liquidity risk. Firms might prefer to issue debt at the lowest current interest cost. One reason is to conserve internal finance. Another reason is that managers have short horizons, and issuing bonds at the lowest interest rate maximizes short-term earnings (as in Stein, 1989). This links the long-term share to the term spread and perhaps to future excess bond returns by coincidence, but does not explain why the long-term share has incremental predictive power over and above the term spread in the Flow of Funds data (Table 5), or why the long-term share is also negatively related to the real short rate and inflation (Table 3 ).

Finally, several lines of argument lead to the principle that debt maturity should be set to match asset maturity, including Myers (1977), Diamond (1991), and Hart and Moore (1995). Graham and Harvey (2001) find maturity matching to be the single most highly cited factor in debt maturity decisions. According to this principle, the long-term share should be positively correlated with changes in aggregate asset maturity. While this still does not connect to future excess bond returns, it does represent a potentially testable implication. We construct a crude measure of changes in asset maturity from balance sheet data reported by the Internal Revenue Service (various issues) Statistics of Income. We estimate the maturity of net fixed assets as the ratio of net fixed assets to depreciation expense and assume that the maturity of all other assets is one year. We then estimate overall asset maturity as the book-value weighted-average asset maturity; the weight on the maturity of fixed assets is net fixed assets over total assets. This procedure is similar to that used in Guedes and Opler (1996). We find that the correlation between annual changes in this asset maturity proxy and the long-term share is negative and insignificant, which differs from the positive correlation predicted by the matching theory. We hesitate to put much value on this result, however. The quality of the proxy for fixed asset maturity is questionable since depreciation expense is dictated as much by tax rules as by economic reality, and our assumption about the maturity of nonfixed assets is even more questionable.

\subsection{Debt market timing}

The discussion thus far casts most doubt on Explanation (1), which requires both that the long-term share's predictive power reflects a rational risk premium and that optimal debt maturity varies inversely with this premium. The evidence for a risk premium is ambiguous, and existing theory gives obscure accounts at best for a negative relationship between optimal debt maturity and subsequent excess bond returns.

Explanations (2) and (3) attribute the behavior of the maturity of debt issues to market timing. There are realistic incentives for managers to try to time the debt 
market. The only requirement is that they care about shareholders. Indeed, many top managers are large shareholders themselves, and most have their compensation otherwise tied to share performance through bonus formulas and stock options.

In addition, surveys of managers essentially prove that debt market timing is an explicit strategy. A substantial fraction of financial managers in the Graham and Harvey (2001) survey state that they issue debt "when interest rates are particularly low." This is the single most highly cited factor in the debt policy decision. Given the decision to issue debt, managers prefer short-term debt "when short-term interest rates are low compared to long-term rates" and when they are "waiting for longterm market interest rates to decline." These are the third and fourth most highly cited factors in the debt maturity decision. (The most highly cited factor is maturity matching, as mentioned above, but this factor does not have an obvious time series implication.) These statements indicate that the relationship between issue maturity and market conditions is not coincidental. Moreover, our Compustat tests, described above, find cross-sectional patterns that are consistent with cross-sectional differences in survey responses.

Debt market timing and equity market timing differ in important respects. Most notable, equity market timing is typically connected to inside information, while (at least among firms with stable credit ratings) debt market timing can only be driven by publicly available information; no firm has inside information about future interest rates. ${ }^{14}$ This is consistent with our results - the predictability that firms use to make debt maturity decisions appears to be the same predictability that is available from publicly observed debt market conditions. Despite this key difference between equity and debt market timing, the basic behavioral principle is the same. Market timing managers are trying to substitute toward whatever form of finance that they think is available at the lowest risk-adjusted cost.

We stress that our results cannot distinguish conclusively between Explanation (2) and Explanation (3). We cannot tell whether firms are following rules of thumb, such as "issue short when the term structure slopes upward," which simply pick up efficiently priced risk factors, or whether they have genuine market timing ability. We find no direct evidence of a risk factor driving the variation in the long-term share, but one may nonetheless be lurking. Huang and Huang (2002) argue that corporate bond default spreads are too large relative to equity risk premia, suggesting that these markets are in fact segmented, and Titman (2002) discusses other evidence of segmentation.

\section{Conclusion}

We find that the maturity of debt issues is closely connected to predictable variation in excess bond returns. Firms tend to issue long-term debt when future

\footnotetext{
${ }^{14}$ Equity market timing may also be connected to publicly available market conditions. Baker and Stein (2002) develop a model in which managers successfully time the market for seasoned equity simply by issuing when the market is particularly liquid.
} 
excess bond returns are predictably low. The long-term share in total debt issues predicts excess bond returns on its own. Interestingly, this predictive power appears largely to reflect its contemporaneous relationships with inflation, the real short-term rate, and the term spread-variables which themselves predict excess bond returns.

The results are consistent with the hypothesis that managers try to time the debt market using publicly available market conditions as a guide to their maturity decisions. It is difficult to tell whether issuing firms are actually reducing the overall cost of capital, however, because of the usual difficulties in interpreting predictability regressions. In any case, the results suggest that theories of debt maturity need to incorporate a larger role for debt market conditions and excess bond return predictability if they are to explain basic patterns in the data.

\section{References}

Baker, M., Stein, J., 2002. Market liquidity as a sentiment indicator. Unpublished working paper, Harvard University.

Baker, M., Wurgler, J., 2000. The equity share in new issues and aggregate stock returns. Journal of Finance 55, 2219-2257.

Baker, M., Wurgler, J., 2002. Market timing and capital structure. Journal of Finance 57, 1-32.

Barclay, M., Smith Jr., C., 1995. The maturity structure of corporate debt. Journal of Finance 50, 609631.

Board of Governors of the Federal Reserve System, various issues. Flow of Funds Accounts of the United States: Flows and Outstandings.

Bosworth, B., 1971. Patterns of corporate external financing. Brookings Papers on Economic Activity 2, 253-279.

Brav, A., Gompers, P., 1997. Myth or reality? The long-run underperformance of initial public offerings: Evidence from venture capital and nonventure capital-backed companies. Journal of Finance 52, 17911822.

Breeden, D., 1979. An intertemporal asset pricing model with stochastic consumption and investment opportunities. Journal of Financial Economics 7, 265-296.

Breeden, D., 1986. Consumption, production, inflation and interest rates: a synthesis. Journal of Financial Economics 16, 3-40.

Brick, I., Ravid, S., 1985. On the relevance of debt maturity structure. Journal of Finance 40, 1423-1437.

Brick, I., Ravid, S., 1991. Interest rate uncertainty and the optimal debt maturity structure. Journal of Financial and Quantitative Analysis 26, 63-81.

Campbell, J., Shiller, R., 1991. Term spreads and interest rates: a bird's eye view. Review of Economic Studies 58, 495-514.

Campbell, J., Lo, A., MacKinlay, A.C., 1997. The Econometrics of Financial Markets. Princeton University Press, Princeton, NJ.

Diamond, D., 1991. Debt maturity and liquidity risk. Quarterly Journal of Economics 106, 709-737.

Duffee, G., 2001. Why does the slope of the term structure forecast excess returns? Unpublished working paper, University of California at Berkeley.

Fama, E., 1984. The information in the term structure. Journal of Financial Economics 13, 509-528.

Fama, E., Bliss, R., 1987. The information in long-maturity forward rates. American Economic Review $77,680-692$.

Fama, E., French, K., 1989. Business conditions and expected returns on stocks and bonds. Journal of Financial Economics 25, 23-49.

Fama, E., Gibbons, M., 1982. Inflation, real returns and capital investment. Journal of Monetary Economics 9, 297-323. 
Ferson, W., Harvey, C., 1991. The variation of economic risk premiums. Journal of Political Economy 99, 385-415.

Ferson, W., Harvey, C., 1993. Explaining the predictability in asset returns. Research in Finance 11, 65106.

French, K., Schwert, G., Stambaugh, R., 1987. Expected stock returns and volatility. Journal of Financial Economics 19, 3-29.

Froot, K., 1989. New hope for the expectations hypothesis of the term structure of interest rates. Journal of Finance 44, 283-305.

Gordon, R., 1982. Interest rates, inflation, and corporate financial policy. Brookings Papers on Economic Activity 2, 461-488.

Graham, J., Harvey, C., 2001. The theory and practice of corporate finance: evidence from the field. Journal of Financial Economics 60, 187-243.

Guedes, J., Opler, T., 1996. The determinants of the maturity of corporate debt issues. Journal of Finance 51, 1809-1833.

Hansen, L., Hodrick, R., 1980. Forward exchange rates as optimal predictors of future spot rates: an econometric analysis. Journal of Political Economy 88, 829-853.

Hart, O., Moore, J., 1995. Debt and seniority: an analysis of the role of hard claims in constraining management. American Economic Review 85, 567-585.

Hodrick, R., 1992. Dividend yields and expected stock returns: alternative procedures for inference and measurement. Review of Financial Studies 5, 357-386.

Huang, J., Huang, M., 2002. How much of the corporate-treasury yield spread is due to credit risk? Results from a new calibration approach. Unpublished working paper, Stanford University.

Ikenberry, D., Lakonishok, J., Vermaelen, T., 1995. Market underreaction to open market share repurchases. Journal of Financial Economics 39, 181-208.

Internal Revenue Service, various issues. Statistics of Income: Corporation Income Tax Returns.

Kaplin, A., Levy, A., 2001. Corporate security issues and asset returns. Unpublished working paper, University of California at Berkeley.

Keim, D., Stambaugh, R., 1986. Predicting returns in the stock and bond markets. Journal of Financial Economics 17, 357-390.

Kirby, C., 1997. Measuring the predictable variation in stock and bond returns. The Review of Financial Studies 10, 579-630.

Lettau, M., Ludvigson, S., 2001. Resurrecting the (C)CAPM: a cross-sectional test when risk premia are time-varying. Journal of Political Economy 109, 1238-1287.

Loughran, T., Ritter, J., 1995. The new issues puzzle. Journal of Finance 50, $23-51$.

Marsh, P., 1982. The choice between equity and debt: an empirical study. Journal of Finance 37, 121-144.

Merton, R., 1973. An intertemporal capital asset pricing model. Econometrica 41, 867-887.

Modigliani, F., Miller, M., 1958. The cost of capital, corporation finance, and the theory of investment. American Economic Review 48, 655-669.

Modigliani, F., Sutch, R., 1966a. Debt management and the term structure of interest rates: an empirical analysis of recent experience. Journal of Political Economy 75, 569-589.

Modigliani, F., Sutch, R., 1966b. Innovations in interest rate policy. American Economic Review 56, 178 197.

Myers, S., 1977. Determinants of corporate borrowing. Journal of Financial Economics 5, 147-175.

Nelson, C., Kim, M., 1993. Predictable stock returns: the role of small-sample bias. Journal of Finance 48, 641-661.

Newey, W., West, K., 1987. A simple, positive semi-definite, heteroskedasticity and autocorrelation consistent covariance matrix. Econometrica 55, 703-708.

Rajan, R., 1992. Insiders and outsiders: the choice between informed and arms-length debt. Journal of Finance 47, 1367-1400.

Ritter, J., 1991. The long-run performance of initial public offerings. Journal of Finance 42, 365-394.

Ritter, J., 2003. Investment banking and securities issuance. In: Constantinides, G., Harris, M., Stulz, R. (Eds.), Handbook of Economics and Finance. North-Holland, Amsterdam, forthcoming. 
Ross, S., 1976. The arbitrage theory of capital asset pricing. Journal of Economic Theory 13, 341-360.

Schwert, G., 1989. Why does stock volatility change over time? Journal of Finance 44, 1115-1153.

Shiller, R., 1979. The volatility of long-term interest rates and expectations models of the term structure. Journal of Political Economy 87, 1190-1219.

Shiller, R., 1996. Why do people dislike inflation? In: Romer, C., Romer, D. (Eds.), Reducing Inflation: Motivation and Strategy. National Bureau of Economic Research, University of Chicago Press, Chicago.

Shiller, R., Campbell, J., Schoenholtz, D., 1983. Forward rates and future policy: interpreting the term structure of interest rates. Brookings Papers on Economic Activity 1, 173-217.

Speiss, D., Affleck-Graves, J., 1995. Underperformance in long-run stock returns following seasoned equity offerings. Journal of Financial Economics 38, 243-267.

Stambaugh, R., 1999. Predictive regressions. Journal of Financial Economics 54, 375-421.

Stein, J., 1989. Efficient capital markets, inefficient firms: a model of myopic corporate behavior. Quarterly Journal of Economics 104, 655-669.

Stigler, G., 1964. Public regulation of the securities markets. Journal of Business 37, 117-142.

Stiglitz, J., 1974. On the irrelevance of corporate financial policy. American Economic Review 64, $851-866$.

Stohs, M., Mauer, D., 1996. The determinants of corporate debt maturity structure. Journal of Business $69,279-312$.

Taggart, R., 1977. A model of corporate financing decisions. Journal of Finance 32, 1467-1484.

Titman, S., 2002. The Modigliani and Miller theorem and the integration of financial markets. Financial Management 31, 101-130.

Van Horne, J., 1984. Financial Market Rates and Flows. Prentice-Hall, Englewood Cliffs, NJ.

White, W., 1974. Debt management and the form of business financing. Journal of Finance 29, 565-577. 